\title{
PERUWIAŃSKA PORAŻKA I PRÓBA JEJ NAPRAWY. WOKÓL POLSKICH MIĘDZYWOJENNYCH KONCEPCJI EMIGRACYJNYCH I KOLONIALNYCH
}

\author{
THE PERUVIAN FAILURE AND AN ATTEMPT \\ TO REPAIR IT. ON POLISH INTERWAR \\ EMIGRATION AND COLONIAL CONCEPTS
}

\begin{abstract}
In the interwar Poland, emigration was considered a possible solution of numerous interior problems of the country. That is why the contemporary Polish authorities believed in the success of colonial plans. In the early 1930s, Peru became a place where these efforts were intensified, encouraged by the president of Peru. The Polish government sent an official commission to this country with the aim to investigate possible settlement in the middle valley of the Ucayali River. The conditions there were found favorable by the Polish officials. In 1927 and 1928, two settlement licenses were negotiated by private entrepreneurs. The article presents the details of this settlement campaign and its final results. Due to a variety of reasons, the action ultimately was a failure, and the Polish government decided to stop it in 1933. Next, it helped its participants leave Peru for Poland or alternatively move to Brazil or Argentina. In the late 1930, Poland returned to an idea of an official license agreement with Peru, this time without the participation of private investors. These negotiations were never completed, however, because in 1939 WW II broke out.
\end{abstract}

Keywords: Peru; Poland; migration; colonial ambitions; 1919-1939

This is an Open Access article distributed under the terms of the Creative Commons Attribution 3.0 PL License (creativecommons.org/licenses/by/3.0/pl/), which permits redistribution, commercial and non-commercial, provided that the article is properly cited. (C) The Author(s) 2014

Publisher: Institute of Slavic Studies PAS [Wydawca: Instytut Slawistyki PAN] 
Międzywojenna Polska w emigracji postrzegała możliwość złagodzenia występujących napięć spoteczno-gospodarczych. Owe wysiłki nazywano planami czy też ambicjami kolonialnymi. Peru na początku lat trzydziestych XX wieku stało się swoistym poligonem tych wysitków przy zachęcie prezydenta tego kraju. Obszary osiedlenia w środkowym biegu Ucayali zostały zbadane, z pozytywnym wynikiem, przez przysłaną z Polski komisję rządową. Równocześnie (1927-1928) prowadzono rozmowy o dwóch koncesjach prywatnych: dla K. Warchałowskiego, urzędnika państwowego i wieloletniego emigranta z Brazylii, oraz Polsko-Amerykańskiego Syndykatu Kolonialnego - obie z powodzeniem. Warchałowski, nie mając wystarczającej sumy pieniędzy, część swojej koncesji na mocy umowy przekazał specjalnie powołanej spółdzielni Kolonia Polska. Jednak akcja Warchałowskiego przyniosła porażkę.Przypadkowy dobór kandydatów do wyjazdu, problemy z komunikacją poprzez oddalenie centrum osadnictwa w Cumarii, szczupłe środki finansowe, biurokratyczna rutyna, nadmierne obietnice, brak jasnego planu, jak również dwuznaczna rola inicjatora, a zarazem przedsiębiorcy wszystko to zawiodło. Syndykat zaś, nie posiadając oficjalnej zgody na nabór osadników, stosował nieuczciwe praktyki zawierania z kandydatami umowy o pracę. Akcja ta kompromitowała Polskę, toteż władze zdecydowały się ją zamknąć w 1933 r., części emigrantów zapewniając repatriację czy wyjazd do Brazylii bądź Argentyny. U schyłku lat trzydziestych Polska powróciła do idei podpisania umowy koncesyjnej z Peru, tym razem na siebie biorąc ciężar negocjacji, rezygnując z prywatnych instytucji. Wybuch II wojny św. przerwał niemal sfinalizowane negocjacje.

Stowa kluczowe: międzywojenna Polska; emigracja; Peru;ambicje kolonialne

\section{PIERWSI POLACY W PERU I POLSKIE ASPIRACJE OSADNICZO-KOLONIALNE}

lednym z ciekawszych i nieznanych epizodów polskiej emigracji oraz tzw. aspiracji kolonialnych - w tym przypadku bardziej metafory niż rzeczywistości - stała się próba kolonizacji peruwiańskiej dżungli przez Polaków. Warto owe wydarzenia przybliżyć i naświetlić, poprzedzając właściwą narrację zarysowaniem historycznego i społecznego tła emigracji polskiej do serca dawnego inkaskiego imperium. Już w XIX w. do niepodległego Peru trafili - czy to uciekinierzy i weterani powstań narodowych, szukający swego przysłowiowego „miejsca na ziemi" i „chleba”: Ernest Malinowski, Aleksander Babiński, Edward Jan Habich, Władysław Folkierski (ojciec), Aleksander Miecznikowski, czy też badacze, naukowcy, architekci lub kolekcjonerzy: Ksawery Wakulski, Władysław Kluger, Ryszard Jaxa-Małachowski, Bruno Paprocki, Konstanty Jelski, Witold Szyszłło. Na nich owa lista wcale się kończy, ponieważ doszły w następnych generacjach i po nowych polskich dramatach kolejne znaczące osoby, choćby familie Rostworowskich czy Potockich (Rodríguez, 1998, ss. 71-88)'. Włożyli oni swój znaczący wkład w rozwój przy-

\section{…..}

E. Malinowski - absolwent krzemienieckiego gimnazjum, prawdopodobnie powstaniec listopadowy (choć są tutaj różne zdanialinżynier drogowy i kolejowy, budowniczy sławnej Kolei Transandyjskiej i obrońca Callao przez Hiszpanami; A. Babiński - powstaniec styczniowy, inżynier górniczy, geolog, topograf; E. Habich - powstaniec styczniowy, inżynier i matematyk, założyciel szkoły górniczej w Limie, która nosi jego imię; W. Folkierski (ojciec) - powstaniec styczniowy, inżynier, matematyk, budowniczy kolei, zarządca żeglugi na Jeziorze Titicaca; A. Miecznikowski - prawdopodobnie uczestnik powstania styczniowego, inżynier, współpracownik E. Malinowskiego podczas budowy Kolei Transandyjskiej; K. Wakulski - inżynier, współpracownik 
branej ojczyzny i wiedzy o niej, poprzez swoją pracę i badania. Zarówno Peruwiańczycy jak i Polacy zdawali sobie z tego dziedzictwa sprawę, czego dowodzi pismo prezydenta I. Mościckiego do jego peruwiańskiego odpowiednika z 1928 r., notyfikujące o nawiązaniu pełnych stosunków dyplomatycznych: „wielu naszych synów znalazło tam gościnę, przytułek i kawałek chleba", co podkreślać miało fakt, że państwo leżące z dwóch stron Andów, to nie jest kraj Polsce obcy².

Niezależnie od tej dobrej historycznej tradycji i miejsca Polaków w pamięci zbiorowej Peruwiańczyków, w międzywojennej Rzeczypospolitej były również rozpatrywane plany polskiego osadnictwa w tym kraju. Kraj nasz wówczas borykał się z licznymi, bolesnymi problemami społecznymi, pogłębionymi przez wysoki przyrost naturalny czy znaczny odsetek mniejszości narodowych i z punktu widzenia kół rządzących emigracja wydawać się mogła jedną z recept na ich rozwiązanie. Już w dobie konferencji pokojowej pojawiły się postulaty, ze strony grupy działaczy emigracyjnych i polityków krajowych, przekazania odrodzonej Polsce części poniemieckich obszarów, z oryginalnym uzasadnieniem, iż Polacy stanowili około 10\% mieszkańców II Rzeszy. W II RP powstały nawet społeczne organizacje propagujące zainteresowanie morzem, emigracją, często określanej mianem kolonizacji przez Polaków obszarów w Ameryce Łacińskiej czy Afryce: Polskie Towarzystwo Kolonialne - od roku 1924 Polskie Towarzystwo Emigracyjne oraz Liga Morska i Kolonialna (od 1930) wraz ze swoją poprzedniczką Ligą Morską i Rzeczną (1924-1930). Na dodatek czynnik mobilizujący mogły stanowić powtarzające się pogłoski o nowym rozdaniu terytoriów mandatowych Ligi Narodów. Także wysuwane raz po raz przez część niemieckich elit żądania oddania choćby części danych kolonii, nie mówiąc o szerszej koncepcji rewizji postanowień wersalskich, mogły motywować niektórych polskich aktywistów do prezentacji własnych pomysłów. Aspiracje kolonialne pojawiały się głównie jednak na użytek krajowy w rodzimej propagandzie. Strona rządowa unikała na arenie międzynarodowej - z różnych względów, od obaw przed narażeniem się na śmieszność, po ryzyko nadwyrężenia relacji z mocarstwami zachodnimi - prezentowania w taki sposób swoich racji. Oficjalnie Polska domagała się szerszego otwarcia dla polskiej emigracji konkretnych kierunków i ekonomicznych korzyści (Białas, 1986, s. 167; Jarnecki, 2010, ss. 93-94; Kopeć, b.d.; Skrzypek, 1995, s. 520; Wrzesiński, 2002, ss. 361-367)3.

Aspiracje, czy idee emigracyjno-kolonialne, miały także znacznie starszy rodowód, wywodząc się z czasu zaborów. W tym przypadku nie chodziło tylko o rozładowanie problemów społecznych. Formułowali je intelektualiści, jeszcze na przełomie XIX i XX w., postulujący "powstanie nowego społeczeństwa - niezależnego od dawnej ojczyzny”, które pozwoli na odrodzenie narodu - zniewolonego lub częściowo zdemoralizowanego w samej macierzy przez lata zaborów. Pierwszym, który tak ujmował kwestie migracyjne, był Piotr Aleksander Wereszczyński, lokalizujący umowną "Nową Polskę" w strefie Oceanii. Tak też na sprawę patrzył w przededniu I wojny światowej Michał Pankiewicz, który już w niepodległej Polsce będzie osobą w sposób znaczący wpływającą na politykę emigracyjną. W pierwszych latach niepodległości kontynuował podobne spojrzenie, jed-

Habicha w pierwszych latach funkcjonowania szkoły górniczej w Limie; W. Kluger - inżynier, budowniczy oraz badacz kultur indiańskich; K. Jelski - zoolog i podróżnik - sponsorowany podczas wyprawy przez Konstantego Branickiego; R. Jaxa-Małachowski - architekt, projektant przebudowy Pałacu Prezydenckiego, ratusza i Pałacu Arcybiskupiego w Limie; B. Paprocki - architekt i projektant Pałacu Sprawiedliwości w Limie, W. Szyszłło - biolog, botanik, badacz peruwiańskiej flory i podróżnik.

2 Archiwum Akt Nowych (dalej AAN), Ministerstwo Spraw Zagranicznych (dalej MSZ), sygn. 743-mf. B16891, Pismo Prezydenta RP z tłumaczeniem na j. hiszpański z 26.10.1928, k. 3-6.

3 Oraz AAN MSZ, sygn. 9585, Tezy polityki emigracyjnej państwa sformułowane przez Departament Konsularny MSZ z 1932, k. 4. 
nak w ograniczonym zakresie, publicysta Gustaw Załęcki, widzący w emigracji, głównie parańskiej z Brazylii, ewentualne wzmocnienie czynników krajowych w dziele budowy państwowości (Fiktus, 2012, ss. 117-121; Pankiewicz, 1916, ss. 17-19).

\section{PERUWIAŃSKI PROJEKT I DWIE INICJATYWY}

Peru jawiło się jako dogodny cel migracji Polaków nie tylko ze względów historycznych i roli przybyszy znad Wisły w podniesieniu tam cywilizacyjnego rozwoju. W latach dwudziestych XX w., w Limie na najwyższym szczeblu zapadła decyzja kolonizacji olbrzymich obszarów podgórskich, które zasiedlić mieli odpowiednio zachęceni europejscy imigranci (Mazurek, 2009, ss. 24-26). Inicjatorem pomysłu był ówczesny prezydent Peru, Augusto B. Leguía, urzędujący w latach 1919-1930. Polska nie posiadała w owym czasie zawodowej placówki w Limie i oficjalne kontakty (nawiązanych wkrótce pełnych stosunków dyplomatycznych) odbywały się za pośrednictwem przedstawicieli RP w sąsiednich państwach. W osobistej rozmowie z postem Rzeczypospolitej w Rio de Janeiro, Mikołajem Jurystowskim, wcześniej pełniącym misję w Grecji, prezydent zachęcał do udziału w projekcie także i Polaków. Wizyta miała miejsce w 1924 r., wiążąc się z obchodami 100-lecia niepodległości Peru. Polski wysłannik przekazał tę ofertę do MSZ (Lepecki, 1930, s. 7; Łossowski, 1995, s. 638)4. Idea spotkała się z odzewem i należytym zainteresowaniem. Sam peruwiański prezydent, zapewne nie tylko ze względów protokolarnych, otrzymał wkrótce najwyższe cywilne odznaczenie Rzeczypospolitej - Order Orła Białego, co też spotkało się z odpowiedzią w następnych latach, w postaci odpowiedniego uhonorowania Polaków (m.in. sławnym "Słońcem Peru")5. Szybko, bo już w 1924 r. grupa biznesmenów, głównie finansistów i bogatych ziemian z Małopolski, utworzyła specjalną spółkę, tzw. Polsko-Amerykański Syndykat Kolonizacyjny (Lepecki, 1930, ss. 7-8, 11; S. Warchałowski, 2009, ss. 24, 27-33) ${ }^{6}$. Pomysł rzucit, jak również inicjatywę polskiego osadnictwa w Peru - Kazimierz Warchałowski, wcześniej wysoki funkcjonariusz Urzędu Emigracyjnego oraz twórca instytucji wpierających emigrację Polaków. W 1925 r. odbywał służbową podróż po Chile, skąd udał się do Limy, aby podjąć konkretne już rozmowy na temat polskiego osadnictwa (Kochanek, 1979, ss. 134-137).

Również AAN MSZ, sygn. 743-mf. B16891, Letters de agreement i nawiązanie stosunków dyplomatycznych; Wręczenie przez posła peruwiańskiego w Paryżu Oscara Barrdy (Polska była w jego jurysdykcji) listów uwierzytelniających, 26.10.1928, k. 2, Informacja z kancelarii Prezydenta RP, bez daty, o nawiązaniu oficjalnych stosunków dyplomatycznych oraz pomysł powołania posła ministra pełnomocnego, k. 3-4. De facto przez większość dwudziestolecia Peru znajdowało się w obszarze konsularnym stałej placówki dyplomatycznej w Buenos Aires, funkcjonowat w Limie Konsulat Honorowy - od 1924 r., dopiero w 1937 r., zdecydowano się na utworzenie Poselstwa w Limie, ale z siedzibą w Buenos Aires, zapewne ze względów oszczędnościowych. Pierwszym takowym posłem łączącym obie placówki został Zdzisław Kurnikowski [M. J.], za: Łossowski, 1995, s. 638 (aneks nr 2).

5 K. Kochanek, 1979, ss. 134-137; AAN, MSZ, sygn. 742-mf. B16890, wśród dokumentów również informacja o uhonorowania kilku Polaków najwyższymi odznaczeniami Peru, w tym sławnego (obok Medalu Niepodległości), „Słońca Peru”: prezydenta S. Wojciechowskiego (być może odpowiedź na polskie honory) i S. Przeździeckiego (wynika więc z tego wniosek, iż premier D. Tusk nie był pierwszym Polakiem - kawalerem „Stońca Peru”).

6 Skład założycieli i zarządu Syndykatu: Stefan Cieński, Sylwester Zajączkowski, Szczęsny Cieński - prezes Rady Nadzorczej, Aleksander Dzieduszycki, wiceprezes Rady Nadzorczej, Władysław Serwatowski, Dominik Łempicki, Tadeusz Żółkiewski, Stefan Dembiński, Julian Brunicki, Juliusz Bielski, Julian Brunicki, Jadwiga Cieńska, Maria Cieńska, Józef Cieński, Ludomir Cieński, Mikołaj Cieński, Stanisław Cieński, Tadeusz Cieński, inż. Władysław Dunca de Sajo, Maria Dzieduszycka, Edward Dzieduszycki, dr Ludwik Roehr - dyrektor Syndykatu. 
Warto naświetlić sylwetkę tego tryskającego energią działacza, który odegrał w tym epizodzie historii polskiego wychodźstwa znaczącą rolę. W latach 1901-1919 wielokrotnie odwiedzał Brazylię, gdzie między innymi badał stan osadnictwa polskiego, zajmował się organizacją szkolnictwa, założył pismo „Polak w Brazylii”. Utrzymywał stałe kontakty z władzami brazylijskimi, przez które został uznany za oficjalnego przedstawiciela spraw polskich w Brazylii; mógł dzięki temu interweniować w wielu sprawach związanych z dobrem emigrantów polskich w tym kraju. W 1921 r. objął stanowisko naczelnika Wydziału Wychodźstwa Zamorskiego w Urzędzie Emigracyjnym (Kopeć, b.d.)7. W 1924 r. jako ekspert brał udział w międzynarodowej konferencji emigracyjnej w Rzymie. W 1925 r. udał się do Ameryki Południowej, jako delegat rządu polskiego, w celu zapoznania się z warunkami osadniczymi. Odwiedził wówczas Brazylię, Argentynę, Chile, Ekwador oraz właśnie Peru. Można zaryzykować opinię, za Jerzym Mazurkiem i Martą Zahoro, iż Kazimierz Warchałowski to człowiek, który niemal całkowicie poświęcił się pracom emigracyjnym (Mazurek, 2009, ss. 8-20, 26-35; Paradowska, 1977, ss. 177-178; Zahoro, 2010), usitując przy tym wiązać - zdaniem autora - swoje osobiste losy oraz prosperity. Z czasem ta podwójna rola, niezależnie od dobrych intencji, okaże się przeszkodą do skutecznych działań. Ogrom zadań także częściowo przerośnie nawet tak energicznego człowieka.

Warchałowski podczas swej wielkiej podróży wystąpił ze współtworzonego Polsko-Amerykańskiego Syndykatu Kolonizacyjnego, z którego członkami poróżnił się podczas początkowo wspólnych starań o własne koncesje w Peru. Arystokratyczni członkowie zarządu wielkopańską manierą zatrzymali się w najlepszym wówczas hotelu Limy, wydając przyjęcia, na które zapraszali syna prezydenta Legui, a pan Kazimierz zamieszkiwał W "skromnym pokoiku" wynajętym przy pomocy konsula honorowego - W. Szyszłly. Nie obeszło się bez pewnych uszczypliwości i niezdrowej rywalizacji (Bochdan-Niedenthal, 1935, s. 138). Warchałowski zapewne też nie chciał być tylko kojarzony z rolą agenta prywatnej firmy, zwłaszcza iż piastował też posadę rządową. Trudno wyrokować dzisiaj, czy wówczas istniał przemyślany plan dwutorowych działań w celu powiększenia obszarów potencjalnej kolonizacji przez zaproponowanie władzom peruwiańskim dwu koncesji. Być może początkowo miały się one uzupełniać. Ostatecznie rząd peruwiański zgodził się na udzielnie dwóch równoległych koncesji osadniczych na obszarach selwy (lasów tropikalnych) - jednej dla Warchałowskiego, na mocy dekretu z dnia 20 maja 1927 r., na skolonizowanie 350 tys., drugiej zaś dla Syndykatu Kolonizacyjnego, na mocy dekretu z 23 kwietnia 1928 r., na milion hektarów. Dokumenty te nakładały, co zrozumiałe, na

Rozporządzeniem Rady Ministrów (RM) z 22 kwietnia 1920 r. została powołana nowa instytucja - Urząd Emigracyjny, do kompetencji którego należały wszystkie sprawy związane z emigracją, imigracją, reemigracją, repatriacją oraz opieką nad wychodźcami. Urząd Emigracyjny (UE) został powołany przy Ministerstwie Pracy i Opieki Społecznej (MPiOS), ale do nominacji dyrektora potrzebne było porozumienie tegoż resortu z Ministerstwem Spraw Zagranicznych (MSZ). Urzędowi podlegały oprócz urzędów pośrednictwa pracy i opieki nad wychodźcami (powołane dekretem z 27 stycznia 1919 r.), ale również Komisarz Emigracji w Gdańsku. Do zadań UE należało: zbieranie i udzielanie informacji zainteresowanym instytucjom i potencjalnym emigrantom o stosunkach panujących w państwach obcych, organizacja przejazdów emigrantów do krajów docelowych, opieka nad nimi w czasie podroży, przeciwdziałanie szkodliwej propagandzie i nielegalnemu werbunkowi oraz ochrona praw i interesów emigrantów w kraju docelowym. Urząd posiadał również szerokie kompetencje w zakresie udzielania koncesji zagranicznym konsorcjom okrętowym na sprzedaż biletów dla emigrantów, co miało pomóc w przezwyciężeniu nadużyć i wysokich cen biletów. Uczestniczył również w pracach legislacyjnych dotyczących spraw wychodźstwa i przygotowaniu konwencji emigracyjnych oraz układów międzypaństwowych. Aby ułatwić UE pracę w zakresie kontroli przestrzegania podpisanych z państwami obcymi umów dotyczących wychodźstwa, została wprowadzona funkcja attache do spraw wychodźstwa - z nominacji MSZ na wniosek MPiOS w krajach, które zostały uznane przez Urząd Emigracyjny za ważne dla polskiego wychodźstwa. MPiOS posiadat też prawo kontroli konkretnych kolonii przez wyznaczonych komisarzy. W Europie utworzono dwie placówki nadzorujące cały ruch emigracyjny i reemigracyjny: w Paryżu i Berlinie (ta druga miała filie w Bohum i Opolu); podstawa prawna wspomniane rozporządzenie RM, [w:] Dz. U. RP nr 39, poz. 232 („Rozporządzenie Rady Ministrów...”, 1920). 
koncesjonariuszy także obowiązki. Warchałowski, działający w podwójnej roli nieoficjalnego wysłannika rządu polskiego i koncesjonariusza, zobowiązywał się sprowadzić do Peru, w przeciągu czterech lat, tysiąc rodzin, składających się przynajmniej z trzech osób, w wieku od 18 do 45 lat. Na jego barki spadał werbunek osadników, ale i organizacja ich przejazdu do tego kraju, łącznie z pokryciem kosztów transportu i osiedlenia kolonistów. W celu skutecznego wywiązania się z tych finansowych zobowiązań, rząd peruwiański przyznał Warchałowskiemu 150 tys. hektarów ziemi, które mógł sprzedać, aby pokryć niezbędne wydatki. Drugi z koncesjonariuszy, Polsko-Amerykański Syndykat Kolonizacyjny, zobowiązany został, również w czteroleciu, do sprowadzenia na swoje tereny koncesyjne trzech tysięcy rodzin osadniczych. W przeciwieństwie do warunków koncesji udzielonej Warchałowskiemu, koszty podróży osadników sprowadzanych przez Syndykat miał pokryć rząd peruwiański. Otrzymane koncesje na zagospodarowanie łącznie 1,5 mln hektarów ziemi, jak się wydawało, stwarzały niewyobrażalne wcześniej i gdzie indziej, wspaniałe perspektywy dla polskiego wychodźstwa osadniczego. Owe dwa dokumenty były jednak tylko pierwszym krokiem i etapem organizacji na większą skalę akcji osadniczej na terenie Peru. Aby lepiej uzmystowić sobie obszary obu koncesji, dla porównania stanowiły one obszar niewiele mniejszy od ówczesnego województwa pomorskiego, licząc ok. 15 tys. km², gdy ich polski terytorialny ekwiwalent wynosił 16386 km² (Lepecki, 1930, ss. 11-17; Mazurek, 2009, s. 26).

Co zrozumiałe, w obliczu zakrojonego ambitnie przedsięwzięcia, do peruwiańskiej Montanii, w celu zbadania możliwości kolonizowania terenów koncesyjnych „elementem polskim", została zorganizowana i wysłana specjalna ekspedycja badawcza. Niezbędnego finansowego wsparcia dostarczyli: Urząd Emigracyjny, istniejący od 1924 r. Bank Gospodarstwa Krajowego (BGK), oraz Polsko-Amerykański Syndykat Kolonizacyjny. Skład został ustalony przez Ministra Pracy i Opieki Społecznej, Stanisława Jurkiewicza w porozumieniu z prezesem Rady Nadzorczej BGK - Romanem Góreckim. Weszli do niej: inż. agronom Feliks Gadomski, naczelnik biura naukowo-informacyjnego w Urzędzie Emigracyjnym, mianowany szefem ekspedycji; Apoloniusz Zarychta, redaktor „Wiadomości Służby Geograficznej”, a później prominentny urzędnik MSZ; Michał Pankiewicz, redaktor „Wychodźcy"; dr Aleksander Freyd, specjalista chorób tropikalnych (kurs w Paryżu); Kazimierz Warchałowski oraz kpt. Mieczysław B. Lepecki. Ponadto towarzyszył wyprawie na swój koszt p. Włodzimierz Orda, ziemianin z Pińszczyzny, oraz p. Merovian, kinooperator, wydelegowany przez paryską wytwórnię filmową Pathé. Odbyła się pomiędzy połową stycznia a połową czerwca 1928 r. Uczestnicy przepłynęli Atlantyk, a potem w górę Amazonki dotarli po obfitującej w dramatyczne przygody (zatonięcie rzecznego statku San Salvador) trasie do peruwiańskiego lquitos. Właściwej wizji lokalnej dokonali w kwietniu i na początku maja. Razem przemierzyli 8885 km w Południowej Ameryce, pokonując kontynent w poprzek. Wracali zaś do kraju z Callao i przez Kanał Panamski. Opinia wydana przez ekspedycję, niezależnie od pewnych zastrzeżeń i wątpliwości dotyczących południowego odcinka koncesji, była pozytywna. Swoje uwagi na piśmie zgłosili Lepecki i Warchałowski, przy czym drugi sugerował celowość w przyszłości przeniesienia ciężaru osadnictwa bliżej lquitos, w rejon na północ od Pucalpy (Lepecki, 1930, ss. 11-17; Mazurek, 2009, s. 26; K. Warchałowski, 1930). Wśród uczestników rekonesansu mógł zastanawiać brak tak wybitnego znawcy flory i warunków naturalnych Peru, jak W. Szyszłło, zadomowionego już od lat w tym kraju. Czy tylko jego praca w limańskim konsulacie honorowym RP mogła stanowić formalną przeszkodę? W jego opinii obszary te nie nadawały się do kolonizacji i były zbyt oddalone od lquitos. Kwestia 2-3 stopni temperatury nie odgrywała tak istot- 
nej roli. Lepszą lokalizację oferowały rejony rzek Napo lub Itaya (Mazurek, 2009, s. 33; Szyszłło, 1955, s. 50; Urbański, 1991, ss. 162-164; Zahoro, 2010). Na powierzchowność i wyrywkowość samych badań i wniosków komisji zwróciła też uwagę Maria Bochdan-Niedenthal, uczestniczka nieudanej próby kolonizacji Montanii (Bochdan-Niedenthal, 1935, ss. 137-138).

Tereny kolonii z Cumarią, gdzie usadowiło się centrum kolonii, należały wówczas do większego niż dzisiaj regionu Loreto (obecnie są to obszary prowincji Atalaya i regionu Ucayali) ze stolicą w lquitos. Obszary koncesyjne Spółdzielni i Warchałowskiego były rozległe (Cumaria w południowej części), zaludnione w niewielkim stopniu i w większości zarośnięte selwą, czyli lasem tropikalnym. Wśród potencjalnych sąsiadów Polaków przeważali wolni Indianie, nieznacznie górujący nad civilizados, czyli Metysami oraz Indianami otwartymi na kontakty z nowoczesnym światem i garstką białych. Teoretycznie na terenach koncesyjnych (200-300 m n.p.m.) miało być nieco chłodniej niż w alternatywnych rejonach lquitos, zdecydowanie lepiej skomunikowanych ${ }^{8}$.

Warchałowski, sam nie posiadając w nadmiarze gotówki, wystąpił w 1928 r. z inicjatywą utworzenia spółdzielni osadniczej, która zgromadziwszy kapitały osób prywatnych, posiadałby odpowiednie fundusze. Do uczestnictwa w przedsięwzięciu zachęcit grono poważanych wówczas obywateli, które utworzyło Spółdzielnię Osadniczą "Kolonia Polska". W dniu 27 czerwca 1929 r. podpisał akt notarialny ze spółdzielnią, odstępując jej prawo do skolonizowania 220 tys. ha z 350 tys., które otrzymał od rządu peruwiańskiego. Spółdzielnia wzięła na siebie zobowiązania sprowadzenia w ciągu czterolecia 1000 rodzin polskich w roli przyszłych osadników, gwarantując to odpowiednimi pieniędzmi. Zgodnie z nowym porozumieniem 50 tys. ha miało przejść na własność osadników, a reszta, czyli 170 tys., pozostawała własnością Spółdzielni. Ta mogła sprzedać ziemię, aby zdobyć środki niezbędne do pomocy kolonistom? ${ }^{9}$.

\section{FIASKO I JEGO PRZESLANKI}

Sprawa nabrała teraz tempa. Po uzyskaniu 8 sierpnia 1929 r. zezwolenia na werbunek osadników do Peru, "Kolonia Polska” rozpoczęła organizowanie akcji emigracyjnej. Jednak międzynarodowy kontekst gospodarczy, w postaci Wielkiego Kryzysu, nie sprzyjał takim ambitnym przedsięwzięciom. Pomimo komplikujących się warunków Spółdzielnia wyprawiła „pierwszą, i jak się później okazało, ostatnią, partię osadników, która składała

\section{$\cdots \cdots \cdot$}

M. Lepecki, 1930, ss. 39-57; także informacje w hiszpańskojęzycznej witrynie internetowej: http:// es.wikipedia.org/wiki/Provincias del_Per\%C3\%BA („Provincias del Perú”, b.d.); AAN MSZ sygn. 9834-mf. B26244, Załącznik pisma MPiOS do MSZ w sprawie ewentualnego wznowienia akcji osadniczej w Peru, z września 1933 r., z memoriałem ppłk. W. Dziewulskiego, ostatniego prezesa „Kolonii Polskiej”, i projekt tego osadnictwa ze strony tegoż prezesa, k. 132-137 - ów dokument został sceptycznie oceniony, w związku z widocznym wówczas fiaskiem akcji.

9 Członkowie-założyciele spółdzielni osadniczej „Kolonia Polska”: senator Stefan Boguszewski, Kazmierz Stołyhwo, E. Kobecki, Zygmunt Nowicki, Stanisław Korwin-Piotrowski, Nikodem Hryckiewicz, Kazimierz Warchałowski, Bohdan Pawłowicz, dr. Aleksander Freyd, ppłk. Wiesław Dziewulski, Jerzy Siła-Nowicki, A. Hutorowicz, Bronisław Herbst, T. Mazurkiewicz, dr Marceli Nałęcz-Dobrowolski, W. Rymarkiewicz, Grzegorz Piotrowski, inż. Włodzimierz Szawernowski, inż. M. Krzyczkowski, Z. Strzemieczny, dr. Gustaw Załęcki. Prezesem zarządu został S. Boguszewski, zastępcą Z. Nowicki, skarbnikiem B. Herbst, sekretarzami komandor Grzegorz Piotrowski i senator Aleksander Iżycki, a szefem Rady Nadzorczej senator Wacław Januszewski za: M. Lepecki, 1930, ss. 11, 18 oraz link „Parlamentarzyści RP” w: www.bs.sejm.gov.pl („Parlamentarzyści RP”, b.d.); też MSZ sygn. 9834-mf.B26244 Wyciąg z umowy (detale) „KP” z K. Warchałowskim z 27.06.1929 oraz pismo do MSZ z 1.04.33 komentujące ten dokument - prawa własności osadnicy nie otrzymali - warunkiem pierwszym przybycia 150 rodzin niespełniony (do 1932 r. 1000 rodzin) , k. 26-28. 
się z 159 polskich emigrantów”, w siedmiu "ratach". Nadrzędnym celem, nawet wbrew zdrowemu rozsądkowi, stało się dotrzymanie warunków umowy koncesyjnej przez organizatorów, którzy wysyłali do Peru maksymalnie możliwą liczbę ochotników, nie zwracając należytej uwagi na ich przydatność zawodową. Koloniści, którzy dotarli w połowie czerwca 1930 r. do Cumarii, centrum koncesyjnych terenów, "zastali tam teren zupełnie nieprzygotowany". Nie wytyczono działek, nie dokonano koniecznego wyrębu dżungli, eufemistycznie nazywanej lasem i brakowało też budynków. "Chaos organizacyjny”, zamieszanie powiększał fakt niewłaściwego doboru osadników, „którzy w większości nie mieli pojęcia o rolnictwie i ciężkiej pracy". Właśnie ów pośpieszny, przypadkowy często dobór ludzi mógł budzić zdumienie. Uczestniczka ekspedycji, Maria Bochdan-Niedenthal (przybyła obok męża wraz z dr. Szymońskim), w sposób barwny charakteryzowała przybyszy, dzieląc ich na trzy grupy.

Jedni to element miejski, przeważnie inteligenci, szukający przygód, marzący o szybkim wzbogaceniu się, o złocie, które niegdyś płynęło strugami z tego legendarnego kraju [...] Bujnej ich fantazji towarzyszyło w większości zupełne nieprzygotowanie do ciężkich warunków życia eksploratora w Montanii, a zawód, jaki ich spotkał w zetknięciu z rzeczywistością, zawsze mniej barwną od legendy, zrobił z nich nieużytków, którzy prędko stali się ciężarem dla kolonii. Drudzy, to wszelkiego rodzaju wykolejeńcy życiowi, ludzie którym z różnych powodów wygodniej było opuścić Polskę, w przewidywaniu, że zdołają sobie zabezpieczyć życie w chaosie nowo powstającej kolonii. Nie brakowało wśród nich wichrzycieli, którzy wkrótce urośli do roli przywódców niezadowolonej większości. Grupa trzecia, to prawdziwi osadnicy, pionierzy. Przy normalnie rozwijającej się kolonii [...], stanowiliby oni grupę dostatecznie silną dla przeciwstawienia się wichrzycielskim wpływom innych. Niestety, w warunkach, w jakich kolonia powstawała, pozbawionych zupełnie koniecznego rozmachu, któryby zdołał porwać nawet najbardziej sceptycznych - grupa ta zmalała do niewielkiej garstki, która mimo panującego nastroju zniechęcenia i niezadowolenia, przystąpiła do pracy na ziemi. Ci ludzie nie różnią się niczym od naszych kolonistów sprzed kilkudziesięciu lat, którzy [...], zyskali Polakom sławę pierwszorzędnych osadników w krajach Ameryki Południowej.

Jak pisała dalej, do tychże najlepszych i niezłomnych zaliczali się ludzie różnych stanów i profesji, jak np. nauczyciel Józef Pieprzyk (tragicznie umrze podczas poszukiwań dogodnych obszarów), niewymieniona z nazwiska rodzina robotnika z Łodzi czy urzędnik kolejowy Nagórski. Ich liderem miał być duszpasterz ks. Franciszek Sokół. Pozostawił on pełen ekspresji opis i charakterystykę przybyszy.

Do puszcz nieprzebytych, gdzie tylko siła pięści i muskułów mogła coś znaczyć, wysłano żądnych szybkiego wzbogacenia się "dyrektorów świeżego powietrza", zebranych z całej Polski. Wszystkie możliwe, wolne i niewolne zawody były tu zgromadzone, najmniej było jednak rolników! Prawie 90 na stu tych osadników nigdy przedtem w życiu nie miało siekiery w ręku. Przychodząc z Ikitosu statki wyrzucały na brzeg Ucayali weterynarzy, pót-inżynierów, ćwierć -redaktorów, byłych oficerów wojsk polskich, tkaczy, kontrolerów biletów tramwajowych, golarzy, flisaków z Narwi, operatorów filmowych, kierowców samochodowych, nauczycieli, tartaczników, rusznikarzy, mieszczuchów i takich sobie synów mamusinych, którzy w Polsce nabroili i których trzeba było gdzieś na jakiś czas schować. Co za zbieranina niedołęstwa i bezwstydu! I to mieli być polscy przodownicy w Peru! (Bochdan-Niedenthal, 1935, ss. 159-160; Mazurek, 2009, ss. 30-31; Sokót, 1931).

Obserwatorzy podkreślali też jeszcze kilka innych kwestii, które mogły zadecydować o porażce. Do akcji przystąpiono, nie znając do końca realiów peruwiańskiego infierno verde, a doświadczenia parańskie (też „puszcze”, ale klimat łagodniejszy), nie do końca były adekwatne. Brakowało szerszego horyzontu, planu (chyba że bardzo ogólny i polityczny), a bieżące racje - wypełnienie warunków koncesji stawało się ważniejsze od zdrowego roz- 
sądku i ludzkiej doli. Na losach „cumaryjskiego eksperymentu” (punkt wybrany z racji, iż ... stał tam gotowy drewniany barak), odbiło się także pomieszanie ról, w których występował Kazimierz Warchałowski. Interes Spółdzielni utożsamiał on zbyt łatwo z własnymi wizjami, może nawet i nie mając złych intencji. Działał często klasycznie „po polsku". Pierwszy dyrektor kolonii, nie posiadając jeszcze zezwolenia na eksploatację lasu, pozyskał grupę francuskich biznesmenów do wyłożenia pieniędzy na tartak wraz z niezbędnymi maszynami. Miał on dostarczać drewna na domy i zapewnić części ludzi pracę. Kwestia przedsiębiorstwa absorbowała odtąd głównie uwagę p. Kazimierza i według wyliczeń Marii Bochdan-Niedenthal, podczas swego urzędowania w roli dyrektora od 24.05.1930 do 21.03.1931 r., w samej Cumarii przebywał tylko 77 dni, resztę spędzając w lquitos bądź Limie, gdzie starał się pilnować „spraw drzewnych”. Formalnie doglądać miał przybywających grup osadników, choć mogli to za niego czynić znający hiszpański miejscowi Polacy, co podkreślała cytowana wyżej obserwatorka. Umowa pomiędzy nim a „Kolonią Polską" dawała Warchałowskiemu większe korzyści, ponieważ po przybyciu 150 rodzin miał otrzymać na własność od rządu 50 tys. ha z pozostawionych sobie koncesyjnych 130 tys. Z tego powinien przekazać Spółdzielni tylko 18 tys. ha. W kolejnym roku uzyskać miał na własność obszar jeszcze większy. Chybioną inwestycją był zakup jachtu motorowego "Janki", który przez duże zanurzenie okazał się nieprzydatny. W jednym z dokumentów, konkretnie w raporcie radcy Michała Pankiewicza, pojawia się też problem innego, dyskusyjnego zakupu, statku do przewozu drewna „Kelinty", o ile autor, co niewykluczone, się nie pomylił i nie stworzył nowego bytu, czy też połączył w jeden dwa obiekty. Równie niefortunnym wydatkiem było dokupienie 1000 ha od Włocha Ferrariego na tyłach Cumarii. W sposób niefrasobliwy gospodarzył finansami akcjonariuszy, ich składkami spłacając stare długi, aby w przyszłości zaciągać nowe. Nie były wypłacane należne pensje lub, jak wskazuje przypadek lekarza dra Zdzisława Szymońskiego, zarząd i dyrektor zalegali mu z wypłatą pieniędzy. Przez ponad pół roku dyrektor nie zdecydował się prowadzić normalnej księgowości i ksiąg kasowych. Także jego cechy charakteru, brak taktu, wybuchowość i temperament iście latynoski, nie sprzyjały relacjom w kolonii. Jego następca z kolei, Aleksander Kurowski, usiłował zakłamaną układnością i obietnicami zjednać sobie osadników, "nową zgodę" pieczętując "suto zakrapianą libacją”, z których jedna zakończyła się awanturą, bijatyką oraz interwencją policji. Posterunek właśnie w ten sposób zainaugurował swoje działanie. Trudne warunki bytowania, kurczące się zapasy finansowe, kłopoty z wyżywieniem - co wynikało z zadłużenia i odległości od baz zaopatrzenia, oraz słabych własnych zbiorów. Budzity zdziwienie inne fakty. "Kolonia Polska" wraz z czynnikami rządowymi znalazła środki, aby opłacić przejazd do Peru osobnikom notowanym w kronikach kryminalnych lub co najmniej dwuznacznym, a miała problem aby zwrócić 80 \$ rolnikowi Józefowi Dziewie za przejazd dziecka. Teoretycznie powinno on płynąć bezpłatnie linią Booth Line. Pomimo braku gotówki zgodziła się na interes uzależniający kolonię od właścicieli statków i łodzi, nie mówiąc już o francuskich partnerach. Kompromitujący kolonię i pośrednio Polskę stał się przedłużający pobyt nowego dyrektora w lquitos, podczas którego musiał dramatycznie się zapożyczać u Peruwiańczyków, co dało powód do niewybrednych docinków. Kurowski często opuszczał Cumarię, pozostawiając osadników na pastwę losu, oficjalnie doglądając przepływu środków finansowych.

Podczas jego nieobecności na czoło wysunął się sprawdzony już w Brazylii, organizator, społecznik - ks. Franciszek Sokół. Niekompetencją, niewiedzą, biurokratyczną rutyną wykazywała się też krajowa centrala Spółdzielni. Dalej wysyłała nieprzygotowanych ludzi, pomimo napływających sygnałów o niewłaściwym ich często doborze. Problemy kolonii, 
mnożone poprzez nieporadne jej administrowanie, powodowały rosnącą frustrację, rozczarowanie, co prowadziło do swarów, wiecowania i strajków, spotęgowanych napływem przypadkowego doboru ludzi, których część zbiegła do lquitos czy nawet Limy. Wśród nich było kilku spryciarzy, jeśli nie przysłowiowych cwaniaków z grona inteligentów, podających się za lotników polskich i wyłudzających pomoc od peruwiańskich kolegów. Większość jednak pozostała nad Amazonką, unikając poza epizodycznymi wypadkami wizyt w Cumarii. Tzw. malkontenci, pojawiając się tam nawet wiosną 1931 r., powiększyli istniejący i tak ferment, a kilku nawet dokonało kradzieży. Część kolonistów, coraz bardziej skłóconych, podenerwowanych, była gotowa nawet pobić Kurowskiego i jego poprzednika. Awanturnicy przesiadujący w lquitos, podczas pobytu Kurowskiego zablokowali hotel, gdzie przebywał i musiał on - co odnotowała z drwiną, żądna sensacji lokalna prasa, postarać się o ochronę policji. Malkontenci oraz zrozpaczeni koloniści pisali skargi do peruwiańskich instytucji, w tym sądów, co zainicjowało kampanię prasową, pełną niechęci do polskiej koIonii. Zagęszczała się atmosfera, tworzył się czarny "pijar”, rykoszetem dotykając II RP. Wylewali pretensje pod adresem nie tylko spółdzielni, ale też instytucji polskiego państwa, które w ich mniemaniu zawiodło. Najlepszym administratorem, a może raczej pełniącym obowiązki, był ks. F. Sokół, doświadczony pionier z Parany, obdarzony autorytetem, jak trzeba sam ciężko pracujący fizycznie. Stało się to jednak w końcu 1931 r., gdy kolonia zaczęła już konać. Świadek i surowy sędzia działań Spółdzielni, sugerowała nawet iż za nieodpowiedni dobór kandydatów na kolonistów mogli odpowiadać jej krajowi członkowie niechętni Warchałowskiemu - a może i rywale z Urzędu Emigracyjnego, aby go skompromitować. On sam cechami swego charakteru i nadaniu priorytetu uzysku drewna oraz interesom z francuskimi partnerami, nawet w dobrej intencji, szanse powodzenia zmniejszał. Jeśli nawet nie przyjmiemy tych gorzkich uwag obserwatorki, która doszukiwała się głębszego dna, to warto przemyślenia jest druga konkluzja. Oto w imię pewnej doktryny, wypchnięcia z przeludnionego kraju części populacji, w tym i elementu niepożądanego, poświęcano losy jednostek, owych przykładowych "Józefów Dziewów, którzy mieli być nawozem, na którym mogła wyrosnąć nad Ucayali Nowa Polska"10.

Drugi z koncesjonariuszy, Syndykat Polsko-Amerykański, oficjalną zgodę na werbunek dostał wiosną 1930 r., ale realnie do niego przystąpit późnym latem. Syndykat uzyskał koncesje na rejony $w$ widłach zbiegu rzek Tambo i Urubamba, na południe od Cumarii i wyżej od niej położone, ale jeszcze gorzej skomunikowane. Dotarł tam wysłannik koncesjonariusza, inżynier Suchorski wraz z 16 pracownikami, Polakami parańskimi, z brazylijskiej prowincji, na pograniczu z Argentyną, którzy do Ameryki Południowej dotarli kilka lat wcześniej. Mieli oni zadanie przygotować obszar i wymierzyć działki dla potencjalnych osadników. Za swoją siedzibę obrał osade Sepa, nazwaną od położenia nad rzeką Sepay, dopływem Urubamby. Po wykonaniu swej pracy, robotnicy wrócili do Parany, a Suchorski ze sprawozdaniem udał się do Warszawy. I w tej partii przybyszy brakowało osób z rolniczym doświadczeniem. Ponoć tylko według świadectwa duszpasterza emigrantów, ks. Franciszka Sokoła, tylko jeden z nich wywodził się ze wsi (Bochdan-Niedenthal, 1935, s. 122; Lepecki, 1930, ss. 58-71).

Syndykat w oczach wyżej cytowanej trzeźwej, choć nie wolnej od ekspresji obserwatorki, dopuszczał się rażących nadużyć. Jej zapiski dowodzą, że nawet nie dysponując rządową zgodą na nabór osadników, podjął nieuczciwą wobec ludzi formę kolonizacji,

\section{....}

10 M. Bochdan-Niedenthal, 1935, ss. 134-156; AAN MSZ, sygn. 9831-mf. B 2624I, M. Pankiewicz do szefa Departamentu Konsularnego (d. DK) MSZ, z 21.06.1931, k. 31-55, gdzie z częścią refleksji autorki wspomnień zgadzał się M. Pankiewicz. 
chcąc się wykazać wynikami przed stroną peruwiańską. Podpisywał z naiwnymi roczne kontrakty, gwarantujące podróż w obie strony, z odpowiednimi płacami, jako pracownikom, a po pokonaniu olbrzymich odległości i po kilkudziesięciu dniach podróży, okazywało się, że owe dokumenty są nieuznawane na miejscu i jeśli zechcą pozostać, muszą podpisać umowy osadnicze. Co gorsza, owe polskie kontrakty Syndykatu posiadały w jej relacji „pieczęcie” Urzędu Emigracyjnego, patrzącego przez palce na jego aktywność, co sfrustrowanych ludzi doprowadziło do drzwi sądów lquitos czy Limie ("drogi bluff") i procesów. Syndykat „chciał przed rządem limańskim wykazać, że w ten sposób udzielonej zaliczki używa rzeczywiście na przejazdy rolników". Owa parodia emigracji, w Urzędzie Emigracyjnym tolerowana, pozwalała „dyskredytować imię polskie w tej części Ameryki Południowej", kojarzone dotąd z wybitnymi rodakami, zasłużonymi w modernizacji kraju. Autorka wspomnień przypomniała wizytę jednego z lokalnych adwokatów, który przynosząc kontrakt, zapytywał się, czy jedna z pieczęci jest rzeczywiście pieczęcią polskiej instytucji rządowej. Dodatkowe szkody dla wizerunku Polski spowodowało wyłudzenie od Peruwiańczyków pieniędzy, co dało potem asumpt prasie do oczerniania Polski. Syndykat też niespecjalnie interesował się swoją koncesją - przedstawiciel zarządu - Gieysztor, pojawił się na krótko i zniknął. Lokalny administrator, niejaki Enrique Urresti, nie czując nad sobą kontroli, zaczął traktować ów rejon jak swoją prywatną własność, zwłaszcza iż jego zdaniem Syndykat był mu winien poważną kwotę kilku tysięcy funtów ${ }^{11}$.

Inna sprawa, że Sepa nie była jeszcze długo „specjalnie atrakcyjna”, ponieważ po fiasku polskiej kolonizacji, stanowiła w latach 1951-1993 kolonię karną, a przez 10 lat wcześniej bazę wojskową. Z czasem obok kryminalistów kierowano tam więźniów politycznych, przeciwników rządu peruwiańskiego, w tym i osławionego Serendero Luminoso („Świetlistego Szlaku”). Ta druga kategoria zdominowała ów swoisty obóz („Penal del Sepa”, b.d.-b).

Ambitną próbę osadnictwa i kolonizacji przez Polaków rejonu środkowego i górnego biegu Ucayali spotkało niepowodzenie. Narastające problemy zainteresowały też zniechęcone czynniki peruwiańskie. Sprawa wyrwała się spod kontroli inicjatorów i musiała zwrócić uwage rządu RP, ponieważ kompromitowała Polske, do której docierały niepełne informacje, pomieszane z plotką. Odczuwalny był brak na miejscu zawodowej, fachowej placówki dyplomatycznej. W Limie funkcjonował tylko konsulat honorowy, a nadzór nad nim sprawowało poselstwo w Buenos Aires. Pracownicy, choć oddani swej misji, nie mieli odpowiedniego doświadczenia politycznego. W owym czasie funkcję tę pełnił znany botanik Witold Szyszłło, następca (od 1926 r.) i współpracownik swego poprzednika, Stanisława Madejewskiego (Smolana, 2010).

Do Peru udał się w celu zbadania sytuacji radca emigracyjny Michał Pankiewicz, posiadający formalne uprawnienia kontrolne w stosunku do "Kolonii Polskiej", występując również w roli delegata rządu. Odbył szereg intensywnych rozmów na miejscu, przemieszczając się energicznie po rozległym kraju. Sporo czasu spędził na statkach sunących po nadających się do żeglugi rzekach oraz w oczekiwaniu na wolne miejsce "aeroplanach", jak również na przerwanie „dzikiego" strajku szoferów.

\section{$\cdots \cdots$}

11 „W roku 1930 wymawiano jeszcze imię Polaka w Peru z pełną czcią i szacunkiem. Ale wówczas było nas tam kilkunastu. Polak to był inż. Tarnawiecki, inż. Paprocki, inż. Malinowski, twórca najwyższej kolei świata w Andach peruwiańskich. Wystarczyły dwa lata naszych wysiłków nad Ucayali, aby wyrobić sobie wśród Peruwiańczyków zupetnie błędne o nas wyobrażenie" i nieco dalej "Nie wystarczyło roztrwonienie setek tysięcy dolarów polskich akcjonariuszy, dla dopełnienia całości potrzebne były te kilkadziesiąt tysięcy, wyłudzone od rządu peruwiańskiego, co po utrąceniu prezydenta Legui, dało powód wytoczenia sprawy Syndykatowi i bezkrytycznego szkalowania w prasie naszych poczynań. Gdyby owe środki zostały zużyte na sprowadzenie pierwszych rodzin kolonistów-rolników, którzy pozostaliby w Cepie, uniknięto by kompromitacji" (Bochdan-Niedenthal, 1935, ss. 127-128, 120-121). 
Oprócz spotkań z pracownikami polskiego Konsulatu (nie zapominajmy, iż honorowego) i miejscową Polonią, rozmawiał w Limie z kierownikami i urzędnikami kilku peruwiańskich ministerstw. Kilka razy odwiedził tutejszy MSZ, docierając do samego kierownika resortu - Larco Herrery. Zawitał w Ministerio de Fomento (czyli dosłownie Gospodarstwa, w domyśle zasobów państwa) i spraw wewnętrznych. Z sarkazmem odnotowywał, iż jego rozmówcy przekonywali o tradycjach wzajemnej przyjaźni, z której duchem powinny być rozwiązane wszelkie problemy, co jednak nie powinno nas, zdaniem Pankiewicza "skłaniać do robienia równie niezyskownych interesów, jak kolonizacja peruwiańska". Zauważył też po peruwiańskiej stronie lęk wobec działań i „planów dalekosiężnych” czy odważnych, ze względu na niepewność swej pracy w administracji rządowej ${ }^{12}$.

Pełniącego obowiązki szefa Konsulatu, zasłużonego przyrodnika inż. W. Szyszłłe oceniał jako naiwnego i niezorientowanego $w$ arkanach dyplomacji amatora, niepozbawionego zapewne szlachetnych intencji. Nie zgadzał się z jego opinią, „iż lepiej na tutejszym gruncie spraw stawiać się nie da". W swych ocenach Pankiewicz był zbyt surowy. Innego osiadłego od lat Polaka, szanowanego tutaj architekta Jaxę-Małachowskiego, także określał przesadnie krytycznie, uważając, iż zbyt silnie utożsamia się on ze swoją nową ojczyzną ${ }^{13}$.

Nie mógł wśród partnerów ominąć sfrustrowanych osadników. Był to trudny dialog z osobami rozgoryczonymi, zdenerwowanymi i nastawionymi roszczeniowo. Kwestią zasadniczą było, jak rozwiązać problem uciekinierów z kolonii, zwłaszcza grupy zgromadzonej w liczbie kilkudziesięciu w lquitos, zgłaszających pretensje finansowe wobec spółki i państwa polskiego. Pomimo iż ich grupka znalazła się też w stołecznej Limie, największy problem przedstawiała sprawa „zbiegów” z lquitos. Według Pankiewicza czynnikiem destrukcyjnym były starania zarządu spółdzielni, aby najdziksze nawet żądania uciekinierów zaspokoić, co demoralizowało ludzi, a przyjazd delegata rozbudził emocje; np. rodzina Gołąbków, która wcale do kolonii nie dotarła, żądała 1000 \$ odszkodowania za stracony czas i zdrowie. Sytuacji nie uławiało pobłażliwe traktowanie pretensji zbiegów przez lokalną administrację, zbytnia wiara w ich prawdziwe czy rzekome krzywdy. Liczył jednak, iż obecność delegata rządu wpłynie na dłuższą metę kojąco na nastroje osadników i uniemożliwi dalsze „występy” prefektury, która przyczyniła się do tego pośrednio. Formułował na gorąco pierwsze wnioski. Kontrakt osadniczy winien zostać zmodyfikowany, z możliwie najmniejszą liczbą zobowiązań ze strony Spółdzielni w trybie warunkowym, iż może pomóc i służyć będzie kredytem. Potrzebny był w Limie stały przedstawiciel rządu minimum z tytułem chargé d'affaires oraz agent konsularny ${ }^{14}$.

W następnych dniach swej misji po drogach i bezdrożach Peru pan Michał rozpatrywał "na szybko" sposoby rozwiązania sytuacji oraz śledził odgłosy lokalnej prasy. Sądził, iż większość uciekinierów powróci, podpisawszy odpowiednie zobowiązania, a część „zagospodaruje" inż. Hansel (obywatel USA szwedzkiego pochodzenia), kierownik komercyjnej kolonii w Yurimagues. Kilku zostanie wyekspediowanych do Brazylii, ponieważ nie można żadnego zostawić w lquitos, z racji sianego fermentu. Niedobra atmosfera wokół polskiej kolonii nad Ucayali, sprzyjała prasowym informacjom o zamiarach zamknięcia czy ograniczenia imigracji z Europy Środkowej do Peru. Pojawiały się problemy logistyczne:

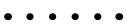

12 AAN MSZ sygn. 9831-mf. B26244, M. Pankiewicz do A. Zarychty, szefa Wydziału Polityki Emigracyjnej - Emigracyjnego I (dalej W.E. I) w DK MSZ z 6.05.1931, k. 2-4 i 8-9.

13 Ibidem, m.in. kąśliwa uwaga, iż "głowa W. Szyszły”, notabene pełna pomysłów, „przypomina śmietnik - 0\% zawartości należałoby odrzucić", k. 5 i o Jaxie Małachowskim, k. 10.

14 Ibidem, M. Pankiewicz do kierownika DK MSZ z 6.05.1931, k. 9-10. 
brak wolnych miejsc na statkach przemierzających Amazonię i szczególnie w samolotach oraz wspomniany strajk szoferów ${ }^{15}$.

Dotarł, ale zajęło mu to sporo czasu, bo należało się „wstrzelić" W rozkłady niezbyt często kursujących parowców oraz samolotów do rejonu Cumarii (najbliższe lotnisko W Masei), zahaczając naturalnie o lquitos. W nieformalnej stolicy peruwiańskiej Amazonii wśród jego rozmówców znaleźli się, oprócz „uciekinierów”, także przedstawiciel linii przewozowej Booth Line i konsul brazylijski. Co zrozumiałe, dla Pankiewicza było istotne, czy da się wyekspediować część niezadowolonych do Brazylii i jakie mogą być tego koszty. Ostatecznie dzięki interwencji nuncjusza papieskiego, dziekana korpusu dyplomatycznego, udało się pomimo wcześniejszych oporów załatwić wizy, dla grupy reemigrantów, a może raczej repatriantów. Brazylijczycy, zapewne przesadnie ostrożni - zażądali w pewnym momencie okazania biletów powrotnych poprzez Atlantyk. Z kolei agent linii przewozowej domagał się od "Kolonii Polskiej” 1000 \$, ale ułagodzony został zadatkiem 1400 peruwiańskich soli. W ten sposób uda się załatwić transport kilkunastu osób - zgodę wyrazili Ziółkowscy, Petzoldowie, Łukaszewicze i niejaki Drozd (prawdopodobnie Ukrainiec). Paszkiewicz zastanawiał się również, czy w pewnych konkretnych wypadkach nie było obcej inspiracji, chociażby w przypadku niejakiego Woltersdorfa, obywatela RP narodowości niemieckiej, który prawdopodobnie zaproszony został do konsulatu Republiki Weimarskiej na rozmowę, a potem żądał biletu do Francji. Ze skupiska w stołecznej Limie, gdzie grupa niezadowolonych przesiadywała w specjalnym hotelu emigracyjnym, także dało się część przekonać do wyjazdu do Brazylii: Podlewscy, weterynarz Sztaba i wyżej wspomniana familia Gołąbków (5 osób, troje dzieci - w tym dwóch synów) - w ostatnim przypadku nie bez teatralnych i dramatycznych scen. Żona Franciszka, Józefa Gołąb, doznała częściowego paraliżu, gdy Paszkiewicz odmówił im pełnej refundacji repatriacji. Rodzina Sieczkowskich z kolei chętnie przystała na transfer do Boliwii. Tym i podobnym tropem pójdą także $w$ dwóch następnych latach działania MSZ ${ }^{16}$.

Swoje głębsze refleksje zawarł w piśmie, o charakterze raportu analitycznego, do szefa Wydziału Konsularnego MSZ, powstałym na pokładzie statku sunącego z biegiem Ucayali, noszącego japońską nazwę „Bokuyo Maru” (w Peru Japończycy stanowili prężną i wpływową grupę etniczną - w przyszłości, jeden z nich zostanie prezydentem kraju). Jak się można domyśleć, jego wnioski nie mogły być optymistyczne. Rozpoczął od konstatacji, iż w rejonie Cumarii, w kraju gdzie fasola i kukurydza wydają plony po 3-4 miesiącach, kolonia nie posiada do tej pory tychże własnych roślin. Został zmarnowany rok ubiegły. Sedno sprawy tkwiło w tym, iż pan K. Warchałowski występuje w kilku rolach - oficjalnie jako przedstawiciel Kolonii Polskiej, jest również posiadaczem części koncesji, komisjonerem rządu peruwiańskiego w sprzedaży terenów i również współwłaścicielem firmy eksploatującej drzewo. Ten fakt, zwłaszcza ostatnia z ról, wywołała przeświadczenie, że kolonizacja jest tylko przykrywką dla interesów prywatnych. Powołał się na rozmowę z Dąbskim, z której wynikało, że o drzewo i zyski z jego sprzedaży tak naprawdę się rozchodzi, a kolonia ma być jedynie do tego pretekstem. Nie mamy pewności, czy taki dialog się odbył, ale oddawał on napiętą atmosferę tego nowego polskiego piekiełka. Sam Dąbski, ziemianin szukający przygód, niekoniecznie był wiarygodnym źródłem [M. J. za M. Boch-

15 AAN MSZ, sygn. 9831-mf. B 26244, M. Pankiewicz do kierownika DK MSZ, z 7, 10 i 12.05.1931, k. 11-16.

16 Ibidem, Szef DK MSZ (notatka) z 20.06.1931, k. 21-26; też AAN MSZ, sygn. 9834-mf. B 26244 Spółdzielnia osadnicza Kolonia Polska, projekty przesiedlenia; DK WE I MSZ do posła w Rio de Janeiro z sierpnia 1933, o konieczności przeniesienia grupy osadników z Peru 35 dorosłych i 16 dzieci z prośbą o wyliczenia oraz pomoc wizową, rozważenie możności osiedlenia w Brazylii osób nienadających się do typowanej na swoisty "ekwiwalent" znajdującej się w tym kraju Aguia Branca, k. 56-57 oraz notatki A. Zarychty, k. 62-63. 
dan-Niedenthal]. To właśnie występowanie Warchałowskiego w wielu rolach przyczyniło się do demoralizacji całej kolonii. Pan Kazimierz miał ponoć dokonać zakupu statku "Kelinty" (możliwe, że pomylił go z „Janką”, o czym wyżej) - do przewozu drewna - co byłoby szczególnym i zarazem nietrafionym przykładem mieszania się interesów. Sprzedaży dokonała żydowska firma "Izrael” - za 2400 \$. Pankiewicz na mocy swoich uprawnień nie uznał transakcji i nastąpić miał zwrot statku, czego nie akceptował "Izrael". Nie udało się ustrzec błędów. Jedna osoba została obciążona nadmiernie obowiązkami administracyjnymi. Zabrakło też planu całej akcji. Nie zostały dotrzymane warunki umowy, w czym nie bez winy była i centrala warszawska, przedstawiająca obietnice bez pokrycia. Zaogniło to stosunki w kolonii, a przy okazji doszło do niewłaściwego, przedmiotowego traktowania imigrantów. Zgadzał się z opinią o niewłaściwej selekcji osadników, zwabionych przesadnymi informacjami o możliwości wzbogacenia się. Co gorsza, doszło do nieuzasadnionego zwolnienia niektórych emigrantów z opłat. Zabrakło też dostatecznego kapitału. Administracja kolonii wykazywała niewłaściwy, biurokratyczny stosunek do przybyszy. W dalszej części zastanawiał się, jak dalej przeprowadzać akcję osadniczo-kolonizacyjną. Koszty przejazdu, minimum 150 \$ na "głowę", były na tyle wysokie, że trudno zdobyć wystarczający "materiał osadniczy”. Eksploatacja drzewa stała się tutaj monokulturą, ale ceny surowca bywały zmienne, a nie zostały wykorzystane sprzyjające możliwości uprawy bawełny i dalej jej obróbki w warsztatach tkackich. Przeceniał chyba Francuza Chenivessa, podawanego jako przykład pozytywny, spławiającego mahoń tratwami, aby obniżyć koszty. Należałoby pana Warchałowskiego rozliczyć, oddając mu równocześnie zasługi. Okoliczności wskazały także na konieczność opracowania strategii osadniczej. Pankiewicz nawet nadmienił, iż doszło do kontaktu z Ministerio de Fomento i byłym już prezydentem Legua, który swego czasu rzucił myśl osadnictwa. Polski delegat miał oświadczyć, że Polska nie ma interesu utrzymywania fikcji w zielonej pustyni i może dokonać repatriacji z Cumarii do Polski czy Brazylii. Wysuwał następujące wnioski:

- przedłużenie czasu próbnego dla kolonii;

- opracowanie dokładnego planu;

- do czasu opracowania takowego planu wypuszczenie z Polski niewielkich grup emigrantów;

- wystanie senatora Boguszewskiego do Cumarii, w celu rozmowy z ludźmi;

- selekcja ochotników;

- wymiana pracowników administracji;

- odsunięcie Warchałowskiego;

- sprecyzowanie warunków umowy osadniczej;

- przekazanie Kolonii Polskiej całości koncesji;

- otwarcie w Limie zawodowego fachowego konsulatu, z chargé de affaires;

- „przeprowadzenie” czyli wynegocjowanie w Limie bezpłatnych przejazdów dla kolonistów i pomocy w akcji.

Pankiewicz konstatował na końcu, iż Warchałowski nie tyle był nieuczciwym człowiekiem, ile nie sprostał zadaniom, zbyt wiele biorąc na swoje barki ${ }^{17}$.

Faktyczne fiasko polskiej akcji osadniczo-kolonizacyjnej w peruwiańskiej Montanii znalazło swoje echo w prasie polonijnej kontynentu. Najboleśniejsze, niewątpliwie niezwykle subiektywne odczucia wyrażał krytyczny list - artykut, w brazylijskim czasopiśmie "Lud" (nr z 10.02.1933) pod sugestywnym tytułem: "Skarga pokrzywdzonego". Jeden z kolonistów prezentował tam swoje żale wobec Spółdzielni „Kolonia Polska” i wspomnianego

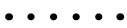

17 AAN MSZ, sygn. 9831-mf. B2624I, M. Pankiewicz do szefa DK MSZ, z 21.06.1931, k. 31-55. 
wyżej mało dynamicznego Syndykatu (obie instytucje pomylono i pomieszano) oraz państwa polskiego. Autor nazywał się Stefan Zioła. Nie był to pierwszy z tekstów krytycznych wobec przedsięwzięcia - poprzedziła go seria redaktora Benradta. Zareagował teraz wysyłając list ze sprostowaniem, znany nam już z wcześniejszej misji, podczas swego pobytu w Argentynie, Michał Paszkiewicz. Prosił w swoim piśmie adresowanym do księdza Pałki - redaktora naczelnego, aby nie jątrzyć, jak się to stało w "Skardze pokrzywdzonego", ponieważ „ukochania dalekiej Ojczyzny, znanej większości pokoleń parańskich tylko z opisów, bynajmniej nie powiększy". Taki tekst stanowi "kroplę", zapewne zatrutą, drążącą sentyment do kraju, a redaktorowi polskiego czasopisma i Polakowi tego „czynić nie wolno!"18. Zabrał też w tej sprawie głos radca ds. emigracyjnych, wydając odpowiedni komunikat i rozsyłając fotokopie do czasopism polskich w Ameryce Południowej, jak "Lud", "Głos Polski” czy „Dom Polski”. Znalazła się tam informacja, iż ostatecznie tzw. Syndykat Polsko-Amerykański z N. Karczewskim ze Lwowa, nie otrzymał zezwolenia od rządu polskiego na sprowadzanie kolonistów do Peru i de facto nikt z jego ramienia nie wyjechat. Spółka „Kolonia Polska” przejęła zaś koncesję Warchałowskiego, wysyłając ludzi. Wydział Konsularny z Poselstwa w Buenos będzie udzielał wiz na wyjazd do Peru dopiero po uzyskaniu przez Syndykat niezbędnych zezwoleń RP i aprobacie wysokości opłat pobieranych od emigrantów oraz innych warunków. Krytyka ze strony pana Karczewskiego, była więc nie na miejscu, a on sam, o podejrzanej przeszłości, zakończył życie w więzieniu ${ }^{19}$.

Warto nadmienić, iż Syndykat próbował grać w swej argumentacji na wysokiej nucie, używając miłej sercu wielu Polaków, w tym decydentów i na pewno Ligi Morskiej i Kolonialnej, retoryki:

„[...] Gdy tereny Syndykatu, jak i Kolonii Polskiej, przytykające do nich od północy, zamykają zupełnie dostęp do połaci kraju sięgającej aż do granicy Brazylii, tak rozległej jak Belgia i Holandia zarazem. Należy się spodziewać, że i na tą wielką połać kraju, koncesja będzie mogła być rozszerzona, np. za zwolnienie rządu Peru z obowiązku wypłacania kosztów przejazdu osadników z Polski do kolonii. W ten sposób mogłoby powstać tam i to bez komplikacji międzynarodowych Dominium polskie, być może ostatnia sposobność nadarzająca się Polsce $w$ tym kierunku wobec zabiegów wszystkich państw o pozyskanie kolonii".

Były to jednak tylko słowa, ponieważ do realnych działań nie przystąpit, grał na zwłokę, pisząc też o rosnących kosztach wyekspediowania ludzi ${ }^{20}$.

\section{PRÓBY RATOWANIA AKCJI PERUWIAŃSKIEJ I JEJ ZAMKNIĘCIE}

Na miejscu ważną rolę odgrywali lekarz kolonii, a konkretnie pełniący tę funkcję dr Z. Szymoński, oraz kapelan ks. F. Sokół. Wagi funkcji - prawnie zagwarantowanej już u zarania „Kolonii" doktora, z racji poważnego zagrożenia chorobami tropikalnymi, nie sposób przecenić. Ten borykał się na miejscu nie tylko ze schorzeniami osadników, głównie różne postacie ropnia (łac. abscessus) i ancylostoma (łac. Ancylostoma braziliense), w postaci pasożyta jelit z rodziny nicieni oraz koniecznością aklimatyzacji. Ponadto musiał pokonywać

\section{•....}

18 AAN MSZ, sygn. 9833-mf. B 26243, Pismo posła M. Paszkiewicza z 17.02.1932 do redakcji „Ludu”. Ksiądz Pałka umieścit sprostowania do niego wysyłane, o czym poinformował radca konsulatu w Kurytybie, R. Staniewicz z pismach do WE I MSZ z 8 i 30.03.1933, k. 7-8.

19 Ibidem, załącznik pisma rady emigracyjnego do pisma z 17.02.1933, gdzie zostały zacytowane uwagi już z maja 1930 r., k. 5-6.

20 AAN MSZ, sygn. 9834-mf. 26244, Syndykat Polsko-Amerykański do MSZ (odpis do Konsulatu Honorowego w Limie), Lwów, 3.10.1932, k. 152-154. 
na miejscu trudności materialne, często mając problemy z zakupem niezbędnych leków, których część - jeśli wierzyć jego wspomnieniom - zakupywał z własnej kieszeni. Narastały zaległości - w pewnym momencie (grudzień 1932 r.) do 580 \$. Szymoński monitował swoje pretensje do MSZ, a te z kolei starało dzielić się swoimi wydatkami z MPiOS. Jego plenipotentem w kraju stał się ojciec, Witold. A środki wypłacane lekarzowi ulegały zmniejszeniu - z jednej strony ze względu na kryzys gospodarczy, z drugiej na dojrzewający zamiar likwidacji kolonii w Cumariii ${ }^{21}$. Ostatecznie stanie się to faktem i po etapie stopniowej redukcji środków na wypłatę, ulegnie tym samym rozwiązaniu umowa o pracę z dr. Szymońskim²2.

W MSZ, MPiOS oraz Urzędzie Emigracyjnym dojrzewała myśl zamknięcia całej akcji peruwiańskiej, aby zmniejszyć nie tylko straty finansowe, ale też prestiżowe i polityczne. Analitycy z MSZ zwracali uwage na konieczność wyegzekwowania środków poniesionych na przeprowadzaną częściową repatriację czy pretensje osadników²3.

Z samej kolonii, a właściwie jej resztek, płynęły dramatyczne apele - pisane przez nowego i ostatniego prezesa, Kazimierza Stołyhwo, o przyznanie subsydiów na pokrycie zadłużenia i wydatków bieżących. Te były niemałe - sięgać miały 4266 \$, a bez tego trudno było godnie zakończyć rachunkową działalność. Przebywający na miejscu, obdarzony autorytetem przez osadników ksiądz F. Sokół, doradzał refundację choćby części poniesionych wydatków, zwłaszcza badań terenowych (nad Urubambą) prowadzonych przez Warchałowskiego i spłatę zadłużenia ${ }^{24}$.W Warszawie odbyło się kilka posiedzeń (28.01. i 22.02.1933) międzyresortowej konferencji w sprawie dalszej kolonizacji i obecności w Peru. Podjęta została decyzja o stopniowej likwidacji inicjatywy peruwiańskiej, ponie-

21 AAN MSZ, sygn. 9832-mf. B26242, dr Z. Szymoński do MSZ z 15.06.31 o chorobach gnębiących osadników i konieczności aklimatyzacji i różnorakiej odporności w klimacie subtropikalnym, k. 1-5; Notatka MSZ o konieczności zwrotu wydatków dr Szymońskiego, k. 6; dr Szymoński o wydatkach z 20.04.1932 i Urząd Emigracyjny MSZ do MPiOS o konieczności wyasygnowania odpowiednich środków - wówczas ekwiwalent 175 \$ z 13.05.1932 oraz pismo z Urzędu Emigracyjnego do MSZ z 20.05.1932 do Prezydium MP i OS o tymże, k. 9-11; Z. Szymoński do MSZ z Cumarii, z 15.06.1932 - wraz ze statystyką schorzeń (nie jedyny raz) oraz dołączony list - skarga o problemach finansowych, cięciach, nawet obniżce pensji przez lekarza ze względu na kryzys i groźba likwidacji polskiej placówki lekarskiej w „Kolonii Polskiej”, k. 15-16; Z. Szymoński do MSZ o chorobach tropikalnych - opis z wyszczególnieniem, z 1.02.1932, k. $30-33$ i 35; DK MSZ do MPiOSz września 1932 r. z prośbą o sprawdzenie czy z Szymońskim była umowa i czy są zasadne jego oczekiwania na wyplatę 55 \& wiosny 1932 oraz z 8.10.1932 - z prośbą o przyśpieszenie odpowiedzi na pismo z września do MPiOS w kwestii wypłaty należności, k. 17-19; Dyrektor Nakoniecznikoff z Urzędu Emigracyjnego do MPiOS z 13.05.1932 o konieczności wyasygnowania 175 \$ dla Z. Sz. z budżetu tego resortu poprzez Państwowy Bank Rolny, k. 37; Pismo ojca - pełnomocnika W. Szymońskiego do WE I MSZ z 27.12.1932 z załącznikiem - zaległościach w wypłatach - należy się 580 \$ i wraz z załącznikiem listu od syna (przed narośnięciem z racji nowych wydatków 487 \$) i zaświadczeniem od ks. F. Sokoła o wydatkach na aptekę z 10.10.1932, k. 23-27; Protokół Komisji Inwentarzowej z 10.10.32 z Cumarii o prawidłowej księgowości w aptece w „Kolonii Polskiej”, k. 34.

22 Ibidem; W. Drymmer, szef DK (notatka) o zmniejszeniu środków wypłacanych Szymońskiemu od 1.12.1933 o 162 zł - z zaległościami 980 zł, a potem już 630 zł + 190 zł zaległości, k. 41-42; W. Drymmer (DK MSZ) informuje rozwiązaniu umowy z dr. Z. Szymońskim ma nastapić z dniem 31.03.1934, do Poselstwa w Buenos, 1.12. oraz 5.12.1933 Warszawa, k. 39-40; W. Drymmer z 25.11.1933 i 5.12.1933 o zmniejszeniu środków wypłacanych Z. Szymońskiemu od 1.12.33 o 162 zł, teraz będzie to 918 zł, k. 41-42; Odręczna notatka Cz. Kulikowskiego z 25.11.1933 r. z informacją, iż resort (czyli MSZ) nie ma zobowiązań wobec dr. Szymońskiego - ministerstwo nie ma z nim żadnej umowy, czyli wypłata środków odbywałaby się z funduszy MPiOS i byłaby swego rodzaju zachowaniem gentelmeńskim, a zapłacić należy koszty utrzymania i za lekarstwa, k. 45; w podobnym duchu również notatka - z uwagą „pilne”, Jana Rozwadowskiego do Wydziału Polaków za Granicą - Emigracyjnego II (dalej W.E. II), z 29.10.1933 - z decyzją o wstrzymaniu poborów do czasu ostatecznej decyzji MPiOS, mogą wynosić najwyżej ok. 200 zł miesięcznie (koszty utrzymania), k. 46.

23 AAN MSZ, sygn. 9833-mf. B 26243, Pismo M. Świrskiego, radcy MSZ do MPiOS z 28.11.1932, k.1; MSZ sygn. 9834-mf. B 26244, przykładem pretensji sprawa Marka Delmera z lquitos, w: MPiOS do DK MSZ z 28.09.1933; przesyła pretensje Marka Delmara z lquitos - do szefów Spółdzielni „KP" z oczekiwaniem na zwrot długów z załącznikiem z 16.05.1933, były to kwoty sięgające 7844,9 peruwiańskich soli, k. 91-103.

24 AAN MSZ, sygn. 9834-mf. B 26244, Pisma od prezesa Kolonii Polskiej, K. Stołyhwo oraz szefa Rady Nadzorczej spółki, do Komisji Międzyministerialnej z 7.12.1932 i 4.03, 1.04.1933, k. 7-9 i 25; List ks. Fr. Sokoła doradzający zastrzyk finansowy dla Kolonii z 2.01.1933, k. 3-4. 
waż na dalsze rozszerzanie osady polskiej w tym kraju nie ma odpowiednich warunków. Do Peru została skierowana informacja o niemożności dalszych subsydiów, ponieważ MSZ odpowiednimi środkami nie dysponuje. W podobnym duchu poszła informacja do poselstwa w Buenos Aires, której teren Peru podlegał. W piśmie nieco na wyrost użyty został argument, iż zdaniem przebywających tam znaczących w kolonii autorytetów: dr Szymońskiego, jak i ks. Sokoła, obszar Cumarii zdecydowanie nie sprzyja osadnictwu. Dla pozostałych jeszcze osadników niezbędna jest jakaś forma opieki i psychicznej podpory, stąd też ze strony resortu padły sugestie i prośby, skierowane na ręce Prymasa oraz Zarządu Spółdzielni „Kolonia Polska”, aby „czas jakiś” pozostał na miejscu energiczny i posiadający zaufanie kolonistów ks. Sokół ${ }^{25}$. Był on na tyle dynamiczny i rzutki, iż usiłował na własną rękę znaleźć optymalne dla kolonistów i sprawy rozwiązania, przekraczając zapewne kompetencje (jeśli tak można byłoby nazwać oczekiwania wobec duchownego). Czy z braku czasu, dystansu, dobrych chęci czasami rozbieżne miewał wnioski. Jeszcze wiosną myślał o przerzucie „niedobitków peruwiańskich” do Brazylii lub Argentyny z lquitos do Manaus (na koszt zainteresowanych), co nie było w sprzeczności z koncepcjami Warszawy. Miejscem docelowym byłaby niedawno założona brazylijska Aguia Branca, której lokalizacja - stan Espirito Santo na środkowym wybrzeżu atlantyckim, nazwa (dosłownie Biały Orzeł) i jakość znalazła wysoką ocenę polskiej dyplomacji. Argentyna trapiona przez kryzys (cytowane kłopoty rodziny Trojanów) w mniejszym stopniu nadawałaby się do przenosin osadników. W przypadku zaś wyjazdu dr. Z. Szymońskiego byłaby to wręcz konieczność. $W$ drugiej połowie roku wystąpił z propozycją przeniesienia kolonistów na tereny koncesjonowane przez brytyjską firmę budującą głównie linie kolejowe, Peruvian Corporation, znajdujące się bardziej na północ, bliżej lquitos ${ }^{26}$.

W opozycji z tezami resortu, co z ludzkiego punktu widzenia zrozumiałe, znalazło się stanowisko zarządzających kolonią, czego dowodziłoby pismo członków Komisji Rewizyjnej Spółdzielni, argumentujące, iż Cumarii należy bronić za wszelką cenę ${ }^{27}$. Ludzie ci zapewne zbyt wiele zaangażowali $w$ to, jak się okazało niepewne przedsięwzięcie i bronili swych decyzji, zasiadając niejednokrotnie i w zarządzie spółki. Polemizowało też w jakiś sposób z ambitnymi koncepcjami i planami ks. Sokoła, z wyraźnymi sugestiami przeniesienia akcji. Także dr Szymoński, czy dlatego iż również począł się identyfikować z polskim osadnictwem w Montanii, czy też z racji, że bronił swojego warsztatu pracy, przedstawiał MSZ swoje przemyślenia i analizy, wskazujące Amerykę Południową jako cel polskiej kolonizacji. Bronił pomysłu osadnictwa w Peru. W marcu, na marginesie uwag o sensie kolonizacji, wytykał brak konsekwencji i sprzeczności w postępowaniu polskich władz. Zaskakujące, iż wysłana w 1928 r. komisja uznała za celowe prowadzenie akcji kolonizacyjnej w Montanii, a teraz władze szukają okazji, aby się wycofać. Pomimo porażki, Polsce emigracja jest niezbędna z racji przeludnienia. Zwłoka jest błędem, ponieważ później może być tylko gorzej, gdyż Peru stanowi dogodny obszar kolonizacyjny. Trudniej bę-

25 Ibidem, Naczelnik WE I w DK MSZ, A. Zarychta do Zarządu Spółdzielni „Kolonia Polska” kancelarii Prymasa Polski z 11.03.1933 wraz z informacją o decyzji Komisji Międzyministerialnej, k. 6-7 i 12; dobitnie poinformował członków spółdzielni w Peru o braku środków W. Jędrzejewicz z MSZ pismem z 11.03.1933, k. 17; Pismo z DK MSZ do poselstwa w Buenos Aires z 23.03.1933 z powołaniem się na opinie Sokoła oraz Szymońskiego, bardziej pogłębione niż konkluzje ekspedycji z 1928 r., k. 20-23.

26 Ibidem, Konsulat Buenos do Poselstwa RP w Buenos z 29.03.1933 z załączonym pismem ks. Sokoła k. 40-41; Interwencyjny list ks. Sokoła z 2.03.1933 i Poseł Mazurkiewicz z Buenos Aires do WEII MSZ z 5.07.1933, k. 49-55; ciekawe informacje o powstaniu Aguia Branca znaleźć można w brazylijskiej wersji Wikipedii, gdzie odnotowany został fakt powstania osady w 1928 r. przez Walerego Koraszewskiego - reprezentanta Towarzystwa Kolonizacyjnego z Warszawy, który podpisał odpowiedni akt z przedstawicielem lokalnych władz stanowych („Aguia Branca”, b.d.).

27 Ibidem, Protokół Komisji Rewizyjnej „KP” z 8.05.1933 z odpowiednią argumentacją, k. 44-47. 
dzie też wybierać, z racji konkurencji i gorszych warunków. Z kolei w swoim czerwcowym memoriale-apelu, iż Ameryka Południowa to "kraj przyszłości i ekspansji emigracyjnej”, wskazywał na niekonsekwencję Komisji Międzyministerialnej z lutego, zalecającej „podtrzymanie jedynego ośrodka kolonizacyjnego w Peru". Podejmowane działania mogły, jego zdaniem, doprowadzić do anulowania koncesji rządu w Limie. W sierpniu też w dramatycznym tonie domagał się wstrzymania jakichkolwiek kroków w sprawie Cumarii. Krytykował też ks. Sokoła, który wbrew zaleceniom Komisji wiąże się z Peruvian Corporation, firmą nastawioną na czysty zysk, która chciałaby uczynić "swoimi wasalami kolonistów" z Polski. Ponadto tereny tego koncesjonariusza graniczą z obszarami malarycznymi. Montania nadaje się mimo wszystko, ponieważ panuje tutaj wspaniały klimat, są dobre i rozległe tereny, a do wad należą, co w Peru jest częstym zjawiskiem, słaba komunikacja i część obszarów koncesyjnych w postaci nieużytków. Lekarz, zapewne skonfliktowany z księdzem, posunął się do sugestii, iż Sokół zdradza symptomy choroby umysłowej28. Część argumentacji Szymońskiego mogła zasiać wątpliwości zarówno w argentyńskim Poselstwie, jak i Wydziale Emigracyjnym, ponieważ resort zwrócił się o ekspercką opinię, o celowość przesiedlenia osadników w rejon kontrolowany przez Peruvian Corporation, zwłaszcza że brak w piśmie Sokoła, rekomendującym pomyst, detali, a także wobec niejasności, czy osadnicy kupują ziemię, czy ma to uczynić rząd RP. Ksiądz posunął się tak daleko jako woluntariusz - negocjator, żeby nie powiedzieć, samozwańczy choć kierowany zapewne dobrymi intencjami, iż wspomniana firma zwróciła się z zapytaniem do polskiej placówki dyplomatycznej w Londynie, czy niejaki Sokół jest znany MSZ. Resort, posiadając pewną wiedze o aktywności księdza, czekał na dokładniejsze ekspertyzy i jego powrót oraz wyjaśnienia duchownego ${ }^{29}$. Sam aktywny, jeśli nie nadaktywny, Sokót, pozytywnie postrzegany przez polskich dyplomatów, czuł się chyba jednak niedoceniony i narastało w nim zniecierpliwienie (jak wcześniej Szymoński), takie zwykłe, ludzkie z racji zaległości w wypłacie należnych mu pieniędzy. Ostatecznie ponosił jako opiekun grupy osadników pewne wydatki i poprzez kancelarię prymasa, któremu raportował o swoich działaniach oraz usiłował naciskać na czynniki rządowe o regulację należności. Te siegały, jeśli wierzyć księdzu, 1590 \$, z czego ponad połowa miała przypadać na jego pensje ${ }^{30}$.

Pomimo dramatycznych apeli grupki osadników, którzy pozostali, polskim zwyczajem podzieliwszy się w efekcie narastającej niepewności i frustracji, czego dowodem ich dwugłos. Część wybrała nowy (ostatni w praktyce) zarząd z ppłk. W. Dziewulskim na czele, zaś mniejsza grupa powołała nową spółkę, „Osadnik Polski” z Teodorem Baranowskim na czele; obie grupy apelowały o utrzymanie kolonii, a nawet wznowienie akcji osadni-

\section{$\cdots \cdots$}

28 Ibidem, Z. Szymoński do MSZ z 30.06.33, k. 58-60; też M. Pankiewicz z Buenos Aires do dr Z. Szymońskiego, z załącznikiem - listem lekarza, z 21.03.1933, informującego, iż przestaje on petnić funkcje radcy emigracyjnego od następnego miesiąca, a od czerwca kończącego pracę w MSZ i w związku z tym wstrzymuje się od komentarza do spraw poruszonych w liście doktora - załącznik, k. 35-39; Z. Szymoński do MSZ z 8.08.1933, gdzie oprócz obrony Cumarii, demaskowania Peruvian Corporation podejrzeń o stan psychik księdza Sokoła, Szymoński apelował o wypłatę zapomóg kolonistom, k. 73-78; Z. Szymoński do Poselstwa w Buenos Aires 30.06. i 24.08.1933, k. 84 i 85-86.

29 Ibidem, Poselstwo w Buenos do WE I MSZ z 19.07.1933 z złącznikiem w postaci listu F. Sokoła z 26.06, k. 66-70 i W. Jędrzejewicz tego samego dnia do Poselstwa w Buenos z zapytaniem o celowość akcji ze zgoda na wypłate 100 \$ za ekspertyze, k. 72-78; Konsulat Generalny RP Londyn do WE II MSZ z 15.09.1933 z zapytaniem w sprawie ks. F. Sokoła wraz z załącznikiem (przetłumaczonym) z Peruvian Corporation o sprawie z 7.09.1933, k. 79-81; odpowiedź: DK MSZ (A. Zarychta) do Konsulatu Generalnego w Londynie z 28.09.1933, k. 90; Konsulat Generalny RP w Londynie z 11.10.1933 o transakcji przeniesienia osadników z zapytaniem, czy Sokół posiada pełnomocnictwa i działa z upoważnienia rządu RP, k. 121; przy okazji uwaga z Wydziału Polityki Emigracyjnej MSZ do Poselstwa w Buenos Aires, 30.10.1933, aby zwrócić uwagę Symońskiemu i Sokołowi, żeby nie zwracali się do centrali bezpośrednio, opóźnia to tok spraw, k. 104.

30 Ibidem, Ks. Sokół do kancelarii Prymasa, Cumaria 24.06.1933, k. 145-146. 
czej31. W Warszawie został jednak przyjęty kurs na likwidację peruwiańskiej inicjatywy i był on stopniowo realizowany. Państwowy Bank Rolny wystąpił wiosną do Sekretariatu banku o wszczęcie procedury egzekucji należności od „Kolonii Polskiej”, nie spłacanej pożyczki 30 tys. zł, otrzymanej dwa lata wcześniej. Jeszcze na wszelki wypadek MSZ zlecił ocenę i skonfrontowanie sprzecznych opinii ks. Sokoła i dr. Szymońskiego z Cumarii. Sokół, po kolejnych rozmowach z brytyjską firmą koncesyjną proponował wysoko położone i chłodne tereny w prowincji Oroya. W okolicach przebiegata linia kolejowa do Callao. Ksiądz przysłał nawet projekt umowy z Brytyjczykami, z rekomendacją terenów koncesyjnych firmy, czekając na odpowiedź. Z analizy dokumentów wynika, iż władze polskie bały się ryzyka i koncepcja nadaktywnego duchownego nie została przyjęta, pomimo przedstawienia projektu budżetu Spółdzielni Cologne de Polaco na rok 1934, w którym znalazłyby się kwoty na transfer tego, co ostało się z kolonii ${ }^{32}$.

W Komisji Międzyministerialnej 24.08.1933 r. zapadła jednak decyzja, aby przesiedlić kolonistów, a dla kilku rodzin pragnących pozostać utrzymywanie kolonii jest nielogiczne i zbędne, o czym też informowali w odpowiednich dokumentach szefowie dwóch wydziałów MSZ zajmujących się emigracją: A. Zarychta i J. Zaleski. Utwierdzały w tym resort opinie posła RP w Buenos Mazurkiewicza. Zadecydował się również los dr. Szymońskiego i ks. Sokoła. W myśl sugestii posła z Buenos Aires, aby obaj panowie puścili oddzielnie placówkę w Cumarii, pierwszy miał zostać zwolniony w najbliższym czasie, a Sokół pozostać przejściowo na miejscu ${ }^{33}$.

Interesujący byłby też fakt, nazwijmy to szczerze - pazerności, nieudolnego drugiego z dyrektorów i członka zarządu „Kolonii Polskiej”, który powrócił do Rzeczypospolitej. Oczekiwał, niezależnie od kondycji kolonii i dramatu osadników, wypłaty zaległych pensji (ponad 15 tys. zł), o co zabiegał na drodze sądowej34.

Należało jeszcze „podziękować” Polsko-Amerykańskiemu Syndykatowi Kolonizacyjnemu, który de facto nie rozpoczął efektywnej akcji osadniczej, niezależnie od górnolotnych zapowiedzi i założeńn ${ }^{35}$.

\section{….}

31 Ibidem, T. Baranowski z Cumarii do DK MSZ, z Cumarii z 5.08.1933, iż koloniści 30.06 wybrali zarząd spółdzielni "Osadnik Polski" w Peru, k. 83; MPiOS do MSZ w sprawie ew. wznowienia akcji osadniczej w Peru -sceptycyzm i załączone pismo-memoriał ppłk. W. Dziewulskiego, ostatniego prezesa „KP”, k. 131-136; projekt planu osadnictwa w Montanii Peruwiańskiej - opracowanie Dziewulskiego bd., k. 137.

32 Ibidem, W. E. I MSZ (A. Zarychta) do poselstwa w Buenos, 30.10.1933, obok wspomnianej wyżej sugestią aby skonfliktowani Szymoński i Sokół nie zwracali się do centrali bezpośrednio, załącznik od Sokoła z rekomendacją terenów Peruvian Corporation i upoważnienie zawarcia umowy z 20.10.1933, k. 104-110; Sokół - rękopis do MSZ z załączonym projektem umowy w j. angielskim i tłumaczeniem z 22.08.1933 wraz z oczekiwaniem na odpowiedź, k. 111-113, tekst angielski projektu, k. 114, a tłumaczenie 115-119 oraz załączoną mapą k. 120; F. Sokół z Cumarii do MSZ, 2.09.1933 z obroną swego stanowiska i oczekiwaniem środków i legitymizacji; swych działań, dołączony projekt budżetu Spółdzielni Cologne de Polaco na 1934 z sumą 9794 \$ na przejazd, a ewentualne aktywy połowa tego 4450 zwroty kosztów wycinki, sprzedaż mienia, zwroty za muly i sklepów - k. 123-125 z 7.09.1933; Państwowy Bank Rolny do Sekretariatu banku z 29.04.1933, o wszczęciu egzekucji należności od „KP", k. 43.

33 Ibidem, J. Zaleski z WE II z 28.09.1933 o decyzji Komisji Międzyministerialnej z 24.08 aby przesiedlić kolonistów wraz z prośbą o konfrontację sprzecznych opinii ks. F. Sokoła i dra Szymońskiego z Cumarii i przy okazji o środki na badania terenowe, k. 88-89; Poselstwo z Buenos Aires (poseł M. Mazurkiewicz) do F. Sokoła z 25.09.1933 z prośbą o sprecyzowanie kosztów, projektu umowy, czy udogodnień ze strony Peruvian Corporation, k. 128-129; Poselstwo z Buenos Aires do MSZ wraz z załącznikami w postaci pism dla Szymońskiego i Sokoła 13.11.1933 z podziękowaniami, sugestia dla resortu, aby dwaj nie od razu opuścili placówkę, k. 140 - też 13.11.1933 do Sokoła, k. 138-142; MSZ do Poselstwa w Buenos Aires z 1.12.1933, Szymoński nie może być zatrudniony, a Sokół jeszcze pozostanie w kolonii, k. 143-144.

34 Ibidem, Pismo A. Kurowskiego do DKMSZ z 5.04.1933 o spowodowanie wyptaty pensji, z racji pełnienia funkcji dyrektora „KP", sąd nawet mu przyznat prawo do 15005 zł (do kwietnia 1932), dokładnie 9542 zł wraz z odsetkami, k. 29-30 i załącznik k. 31-33; Poselstwo RP w Buenos do Wydziału Emigracyjnego MSZ, z 17.07.1933, z prośbą o szybką odpowiedź w sprawie nadpłaconych 200 \$ Kurowskiemu, oraz zapytaniem jak sprawa się ma, 17.07.1933, k. 65.

35 Ibidem, Wydziat Konsularny MSZ do Poselstwa w Buenos Aires MSZ z 23.03.1933, sygn. 9834-mf. B 26244, z informacją, że koncesja Syndykatowi na razie udzielona być nie może z braku dostatecznych, k. 23; Pismo 
Gdy zabrakło środków finansowych i skandal wokół sprawy przedostał się do szerszej opinii publicznej, władze polskie jak i peruwiańskie przerwały wspierać przedsięwzięcie, a kolonie niemal opustoszała i zarazem wygasła ważność koncesji zarówno Syndykatu jak i Kolonii Polskiej, została ogłoszona upadłość inicjatywy ${ }^{36}$.

\section{KONTROWERSJE WOKÓL KONSULATU HONOROWEGO PERU}

Niezależnie od fiaska pierwszej próby akcji osadniczo-kolonizacyjnej pojawiły się na horyzoncie relacji polsko-peruwiańskich jeszcze inne kwestie, niekoniecznie wzmacniające wizerunek II RP. Nie umacniały prestiżu również kontrowersje związane z atmosferą wokół obsady personalnej Konsulatu Honorowego Peru w Warszawie w drugiej połowie lat trzydziestych, ocierające się o aferę lub momentami farsę (np. zgłoszenie własnej kandydatury). W listopadzie 1935 r. tę zaszczytną funkcję objął po niejakim J. Brygiewiczu, biznesmen Kazimierz Szczerba-Likiernik. Po dwóch latach z biura Protokołu Dyplomatycznego przyszło do Rady Ministrów poufne pismo z prośbą o sprawdzenie, czy konsul nie ma powiązań z aferzystą Maksymilianem Kamieńskim, mającym proponować za pieniądze, konkretnie 10 tys. zł., objęcie tej placówki dla „znajomego". Sam Kamieński został zatrzymany w firmie Warszawskiego Towarzystwa Handlu Herbatą (WTHH), dla którego prezesa, niejakiego Wiśniowskiego, o wspomnianą godność zabiegał. Zapewne motywem mógł być przysługujący tej funkcji częściowy choćby immunitet dyplomatyczny. U samego Szczerby-Likiernika, podczas zarządzonego „przeszukania”, została znaleziona jego wizytówka z informacją, iż jest przedstawicielem polsko-sowieckiej izby handlowej. Podczas rozmowy stwierdził, że miał zamiar opuścić kraj, poszukiwał kandydata na następcę, upoważniając do tego znajomego mu Kamieńskiego, ale nie do działań korupcyjnych. Jakby tego było mało, pojawił się kolejny wątek. Przejściowo kierował placówką podczas jednego z wyjazdów Likiernika, niejaki Roman Liban zatrudniony w Polsko-Peruwiańskiej Izbie Handlowej, z którą i konsul posiadał związki. Prezesem owej instytucji był Samson Mikiciński, niezależnie od szefowania Poltourem, podczas wojny domowej w Rosji, walczący po stronie białych z bolszewikami. Niestety, wzorem uczciwości nie był, stwierdzono bowiem z jego strony oszustwa i wyłudzenie 350 zł. Miał w swoich kontaktach, dla zwiększenia prestiżu, powoływać się na rzekomą funkcję wicekonsula Peru. Wokół placówki narosło tyle wątpliwości, że zarówno strona peruwiańska, konkretnie ambasada w Paryżu, której podlegał konsulat honorowy w Warszawie, jak i Polska zastanawiały się nad jego zamknięciem. W AAN nawet znajduje się notatka z ambasady paryskiej, iż Peruwiańczycy mieli zrezygnować w listopadzie 1938 r. z osoby Likiernika, co nie przeszkodzito stronie polskiej korzystać z jego usług w roku następnym, zapewne ze względu na jego doświadczenie ${ }^{37}$.

nowego konsula honorowego Mariana Tarnawieckiego (po W. Szyszłto) do Ministerio de Fomento w sprawie Polsko-Amerykańskiego Syndykatu Kolonizacyjnego z 30.11.1933, iż ten jeszcze nie posiada odpowiedniej kwoty, k. 151; też w tej samej teczce cytowany już list Syndykatu do MSZ i odpisem dla konsula, z 3.10.1932, k. 153-154.

36 AAN MSZ sygn. 9832-mf. B26242, Odręczne pismo Cz. Kulikowskiego do MSZ z 25.11.1933 o upadłości Spółdzielni Kolonia Polska i wypłacaniu dr. Z. Szymońskiemu kosztów utrzymania i lekarstw. Lekarz nie ma żadnej umowy z MSZ, k. 45; Zahoro, 2010.

37 AAN MSZ, sygn. 744-mf. B16892, k. 3/4 Prezydent I. Mościcki do MSZ, 19.11.1935 z informacją, iż po otrzymaniu listów uwierzytelniających, upełnomocnił Konsula Honorowego Peru Adolfa Kazimierza Szczerbę Likiernika (używał de facto drugiego imienia) oraz zawiadomienie szefa biura prasowego Rady Ministrów (RM) Berezowskiego 22.11.1935 o zastąpieniu J. Brygiewicza, k. 5 i 10; k. 18 Biuro Protokołu Dyplomatycznego 
Sprawa niejasnych powiązań Szerby-Likiernika w przeszłości powróciła wiosną 1939 r., gdy został on wezwany do MSZ na rozmowę w kwestii związków ze wspomnianym Mikicińskim i niejakim Levensonem, osobami co najmniej dwuznacznymi. Były konsul - tytułowany jednak nadal w ten sposób, oświadczył, że owszem, Mikicińskiego zna, lecz kontaktów nie utrzymuje ze względu na kryminalną przeszłość rzeczonego. Levenson był zaś jednym z jego poprzedników. W swoich konkluzjach Wydział Emigracyjny (I), uznał za właściwe odebranie obu podejrzanym paszportu i dokumentów o pełnionej przez nich funkcji w radzie konsulatu peruwiańskiego. Sam Szczerba-Likiernik miał być „w porządku”, a Mikicińskiemu funkcję miał obiecać jeden z peruwiańskich generałów, obecny na zawodach strzeleckich w Toruniu w 1932 r. i stąd wzięło się przywłaszczenie tytułów (Levenson był kolegą pana Samsona). Likiernik przestrzegał, co zostało udowodnione przed nim peruwiańskiego chargé d'affaires z Pragi, Jose Gambettę, gdy ten zjawił się W Warszawie ${ }^{38}$.

\section{ZABIEGI O NOWA KONCESJE}

Ze względu na kompletne fiasko pierwszej poważnej próby polskiego osadnictwa, czy jak to nazywano - kolonizacji w Peru, łatwiej zrozumieć, podjęte ponowne starania przez czynniki odpowiedzialne za emigrację, u schyłku lat trzydziestych. Miało to zatrzeć fatalne doświadczenia i nadszarpnięty prestiż II RP. Działania takowe zapoczątkował sekretarz, wcześniej chargé d'affaires Poselstwa w Buenos Aires, Wacław Dostal na początku 1939 roku. Dokładnych dat dziennych nie znamy. Zaczęło się od wysłanej do Argentyny informacji przez wicekonsula W. Wrońskiego, o przeznaczeniu pod kolonizację przez pe-

\section{$\bullet \bullet \bullet \bullet$}

MSZ do Komisariatu RM, z 5.10.1937, z klauzulą poufności z prośbą o sprawdzenie czy Szczerba Likiernik nie posiada związku z aferzystą M. Kamieńskim, który miał proponować za pieniądze objecie konsulatu honorowego Peru k. 18; korespondencja Biura Protokołu Dyplomatycznego MSZ z Komendą Policji Państwowej z października 1937 r. , o zatrzymaniu w WTHH M. Kamieńskiego, wraz z raportem policyjnym o propozycjach korupcyjnych zatrzymanego, kupna funkcji konsula za 10 tys. zł - za pośrednictwem n. M. Byszewskiej oraz relacja policyjna z rozmowy ze Szczerbą-Likiernikiem i wynikach „przeszukania”, k. 20, 22-23; Roman Liban do DK MSZ z 14.10.38, z informacją o tym iż zastępował konsula Likiernika między czerwcem sierpniem 1938, k. 25; Prezes Rady Izby Handlowej Polsko-Peruwiańskiej, inż. A. Kamieński do MSZ z 14.04.1939, z informacją, że dyrektorem jest p. Samson Mikiciński, k. 30; o tymże S. Mikicińskim, jego dwuznaczności, m.in. wyłudzeniu pieniędzy, z MSW do MSZ, z 13.08.1938, k. 33; MSZ do MSW, z 11.08.1938, iż S. Mikiciński podawał się za rzekomego wicekonsula Peru, k. 34; Biuro Protokołu Dyplomatycznego MSZ do DK MSZ, z 13.06.1938, informujące, że ów Mikiciński jest tez szefem Poltouru oraz wniosek z ekspertyzy do Dyrektora Gabinetu Ministra, Michała Łubieńskiego, aby Konsulat Honorowy zamknać w jego obecnym składzie i przybudówkami, k. 35-40; dowodem, że strona peruwiańska interesowała się losem otoczonej dwuznaczną sławą placówki, pismo z Ambasady RP w Paryżu do MSZ z 27.10.1937 (placówka w Warszawie podlegała ambasadzie peruwiańskiej nad Sekwaną) z pytaniem czy Likiernikowi cofnięto zezwolenie, k. 57; Ambasada RP w Paryżu do MSZ z 1.02.1938, iż p. Tavara, ambasador Peru sugeruje cofnięcie zgody Szczerbie-Likiernikowi oraz późniejsze pismo z Paryża, z 23.11.1938, z informacją, że Likiernik został zwolniony z tej funkcji, k. 60 i 62; dowodem pewnej niejednoznaczności w interpretacjikwestii odebrania mu godności, dokument w: AAN MSZ sygn. 9556-mf. B25966, Odręczna notatka szefa Międzyministerialnej Komisji Emigracyjnej (MKE), dr A. Zarychty do Komisji Dewizowej MSZ, z 8.05.1939 r. iż do Peru udaje się jako delegat MTO i z ramienia MSZ K. Szczerba-Likiernik, nazywany tam konsulem honorowym Peru, k. 57; warto też wspomnieć o wypadku zgłoszeniu własnej osoby jako kandydata na konsula honorowego Peru, co uczynił dr Jerzy Machlejda, w: AAN MSZ, sygn. 9556-mf. B25966, Jerzy Machlejda w liście do MSZ z 21.08.1937. Był to prawnik, dyrektor Firmy Zakłady Ogrodnicze C. Ulrich, a MSW w dniu 16.08.1938 r. wydało mu dobra opinię, k. 1 i 10; MSZ sygn. 9557-mf. B 25967, Telegram szyfrowy z Buenos do MSZ, z 26.05.1939 o tym że Peru zrezygnowało z jego osoby jako konsula honorowego, k. 6; WE I MSZ do Poselstwa z Buenos, bd, ale wynika, że z czerwca 1939 r. W.T. Drymmer odpowiadał, iż pomimo znanego faktu, pozbawienia Likiernika godności konsula, decyzja o posłużeniu się jego osobą, wyszła ze strony resortu, k. 2; Biuro Personalne do Poselstwa w Buenos Aires z konkluzją, iż zastrzeżenia wobec Likiernika były raczej pośredniej natury i stąd informacje posła Kurnikowskiego są niedokładne, 2.06.39, k. 5.

38 AAN MSZ, sygn. 9556-mf. B25966, Umowa emigracyjna polsko-peruwiańska, Notatka WE I z relacją z rozmowy z Likiernikiem w kwestii kontaktów z Mikicińskim i Levensonem, osobami o dwuznacznej przeszłości, Warszawa 31.05.1939, k. 121-123. 
ruwiańskie władze obszarów wokół Tingo Maria, rzędu 500 tys. ha. Jako że Argentyna w tym czasie zamykała swoje granice, zastanawiali się polscy dyplomaci, czy Peru nie zechce pójść w jej ślady. Przygotowania do jego wizyty inspekcyjnej w Chile i Peru, zostały podjęte w listopadzie 1938 r. i zapewne niedługo później Dostal opuścił Buenos Aires. Występował w roli nie tylko dyplomaty, ale i pośrednio reprezentanta Międzynarodowego Towarzystwa Osadniczego (MTO), spółki powołanej przez MSZ w 1936 r. Udał się on do Peru i podjął negocjacje z czynnikami peruwiańskimi. Rokowania prowadził w znanym nam już Ministerio de Fomento i Departamencie Imigracji MSZ. Głównymi rozmówcami byli inż. Cisneros, oraz dyr. Recavarene, ponoć referujący sprawę samemu, ówczesnemu prezydentowi Benavidesowi. W międzyczasie doszło do kryzysu rządowego, ale Polakowi udało się dotrzeć i porozmawiać na pół nieformalnie z samym prezydentem. Podczas rozmów nie pomagały Dostalowi, o czym m.in. raportował zastępca konsula honorowego, Włodzimierz Wroński, plotki wzbudzające obawy o wzmożony napływ Żydów z Polski i pozbycie się problemu kosztem Peru. Było to o tyle warte odnotowania, ponieważ przyjazd sporej grupy z Niemiec i Czechosłowacji, spowodował wybuchy antysemityzmu. Do tej kwestii wracali jeszcze kilkakrotnie pracownicy MSZ, a zwłaszcza Poselstwa w Buenos Aires - od roku 1937, posiadającego także swoją drugą siedzibę i w Limie. Peruwiańczycy mieli pewne podstawy do swoich niepokojów, ponieważ na wiosnę 1939 r. spłynęło kilkadziesiąt, jeśli nie ponad setka podań o wizę obywateli polskich pochodzenia żydowskiego. W prasie ukazać się miało kilka alarmistycznych artykułów. W kwietniu zaniepokojony poseł Kazimierz Zdzisław Kurnikowski udzielit nawet reprymendy pracownikom Konsulatu w Limie, że ci nie dali jasnej odpowiedzi, czy prawdziwymi są docierające pogłoski o niechęci dania wiz polskim Żydom przez władze peruwiańskie ${ }^{39}$.

Warszawska centrala MSZ była zadowolona z efektów „sprężystej” pracy Dostala, i zastanawiała się nawet nad nadaniem odznaczeń zaangażowanym osobom . Tenże sam szef Departamentu Konsularnego i Wydziału Imigracyjnego, Wiktor T. Drymmer, zastanawiał się nad koniecznością wysłania dwuosobowej misji w celu weryfikacji, po różnych doświadczeniach (np. z Boliwią, nie mówiąc o samym Peru), nowej umowy koncesyjnej uzgodnionej z rządem w Limie $^{40}$.

\section{$\cdots \cdots \cdots$}

39 AAN MSZ, sygn. 9557-mf. B 25967, Wicekonsul RP w Limie - W. Wroński, do Poselstwa w Buenos Aires, z 21.09.1938, o Tingo, k. 144 i 148; Poselstwo Buenos Aires do MSZ 4.10.38 o możliwościach w Peru, k. 145-146 oraz WE IMSZ do Poselstwa w Buenos (pocztą lotniczą), z listopada 1938, aby w planowanej podróży inspekcyjnej sekretarz Dostal poruszył także kwestie negocjacji umowy imigracyjnej z Peru, k.139141; AAN MSZ, sygn. 9556-mf. B25966, W. Wroński do Poselstwa w Buenos Aires, z 25.02.1939, gdzie donosi, iż wie z kilku źródeł, w tym od anonimowego informatora (nazwiska celowo nieujawniane), że pewna osoba o polskich korzeniach prawdopodobnie urabiała opinię o możliwości masowego napływu Żydów ze Środkowej Europy, k. 92; Sprawozdanie W. Dostala z rokowań w Limie, z 16.04.1939, k. 9-15; Poselstwo w Buenos Aires (K.Z. Kurnikowski) z 19.04.39 wyrażające oczekiwanie na powrót W. Dostala z załącznikiem z postaci pisma z konsulatu honorowego w Peru (W. Wroński), z 5.04.1939 o trudnościach zaistniałych z imigracją z Polski i obawy przed napływem Żydów (nie bez pewnych podstaw - liczne podania o wize czy obywatelstwo w j. hiszpańskim), jak również artykułach prasowych, z cytowanym tytułem „Polska chce się pozbyć swoich Żydów kosztem Peru". Te względy znacząco ograniczyły możliwość aktywnego włączenia się konsula i jego zastępcy do rozmów o nową umowę emigracyjną, k. 89-90; Poselstwo w Buenos i Limie (K.Z. Kurnikowski) do konsula honorowego w Limie, 19.04.1939. List posada charakter jeśli nie nagany, to krytyki działań placówki. Konsul miał jasno poinformować, czy urzędy peruwiańskie otrzymały zadanie nieudzielania wiz polskim Żydom czy też nie, oraz czy istnieje kwestia polska w Peru. Konsul powinien też udzielać wszechstronnej pomocy sekretarzowi poselstwa z Buenos, W. Dostalowi wprowadzonych rokowaniach. Pisma konsulatu - konkludował Kurnikowski, czynią wrażenie że są przygotowywane pobieżnie i konieczne jest wytkniecie zaniedbań, k. 91; Tajna notatka z DK MSZ do MPiOS (bd - ale z kontekstu wynika, że z kwietnia) o finalizacji rokowań o umowę z projektem umowy, projektem tajnej noty i odpis instrukcji do poselstwa w Buenos Aires, k. 61

40 MSZ sygn. 9557-mf. B25967, DK MSZ (W. Drymmer) do W. Dostala, z gratulacjami za ustalenia w Peru i Chile, ale i niedosyt, z racji, że nie odwiedził podczas 1,5 miesiąca obszaru Tiengo Maria, k. 160-161, W. Dostal z Limy do Naczelnika WE I A. Zarychty z opisem podróży do Limy i prowadzonych negocjacjach 26.04.1939, k. 162-164; AAN MSZ, sygn. 9556-mf. B25966, Komunikat Dyrektora DK MSZ, Warszawa 8.05.1939 o chęci 
Jakie były rezultaty rozmów W. Dostala? W swoim sprawozdaniu na wstępie zaznaczał, iż udało się objąć Polaków postanowieniami ustaw o kolonizacji wewnętrznej, co uznawał za korzystne. Peruwiański rząd zobowiązał się utrzymywać Polaków przez 14 dni od wylądowania, i na własny koszt wyciąć 1 ha lasu i zasiać produktami strefy, gdzie ma się odbyć kolonizacja. Dodatkowo (cytował zapis tajnej noty) miał bezpłatnie przekazać dom mieszkalny na własność, narzędzia i nasiona o wartości 50 soli, niezbędne do pracy nad przygotowaniem każdej działki oraz inwentarz żywy wraz z materiałami budowlanymi wartości 300 soli (wówczas 1 sol to 1.1 zł). Owe korzystne finansowe ustalenia miały dotyczyć 100 rodzin w pierwszym roku umowy, $200 \mathrm{w}$ drugim, $500 \mathrm{w}$ trzecim i 400 od czwartego roku do końca 10-letniej umowy. Interesujące, iż zostały także wyznaczone działki dla nieletnich członków rodzin kolonistów: 10 ha dla osadników 14-18 lat, a 20 ha 18-21 lat, co stanowito dodatkową zachętę. Tereny przeznaczone do kolonizacji przez Polaków znajdowały się w rejonie Tingo Maria, około 12 godzin od Limy. Sekretarz załączał także wynegocjowany dokument, a de facto jego projekt, który oprócz formalnego podpisania, wymagał procedury ratyfikacyjnej. Poseł Kurnikowski miał zaaprobować te ustalenia, ale sam gotowy projekt, z racji braku możliwości pozostania dłużej w Limie, przesłany został do Buenos Aires. W MSZ istniała wola szybkiego sfinalizowania, jak ją nazywano - „umowy z Buenos Aires”, aby jeszcze w tym samym 1939 r. mogli wyjechać pierwsi osadnicy i z jej zapisów skorzystać. Dostal także w swoich przesłanych uwagach mobilizował do finalizacji umowy negocjowanej w Limie, głównie z powodu perturbacji na peruwiańskiej scenie politycznej.Te zmusiły go szybszego opuszczenia Limy, jeszcze przed parafowaniem umowy. Okoliczność, że zaufani potwierdzali wartość Tingo Maria, jak i fakt aprobowania umowy przez najwyższe czynniki, wskazywały jednak rozpocząć kolonizacje już w tym roku41. Sama szczegółowa umowa koncesyjna, miała zostać opracowana przez MTO, do którego powinności należało przeprowadzenie inspekcji i badań rejonu Tingo Maria. W MSZ i placówce w Buenos Aires ponownie, jak przed laty, personel Konsulatu Honorowego w osobie szefa - Mariana Tarnawieckiego i jego zastępcy Włodzimierza Wrońskiego, nie cieszył się specjalnym zaufaniem, z racji wątpliwości do ich zdolności negocjacyjnych. Zapadła też decyzja o wysłaniu dwuosobowej misji, w osobie znanego K. Szczerby-Likiernika i prawdopodobnie, uważanego za eksperta inżyniera Klasę. Oprócz wizji lokalnej miała wynegocjować detale ${ }^{42}$. Przygotowania do wyjazdu nabrały konkretnych kształtów, choć w dokumentacji dotyczącej tej kwestii znikło nazwisko inżyniera. Nie do końca jednoznaczny był status przyszłego negocjatora. W jednym

\footnotetext{
i konieczności jak najrychlejszego podpisania wynegocjowanej umowy emigracyjnej oraz o wymianie odznaczeń dla zaangażowanych osób, k. 2-3; Poselstwo w Buenos Aires Buenos do DK MSZ, z 19.05.39 z informacją, że stronie peruwiańskiej też zależy na szybkiej realizacji, już gotowa przyjmować osadników, należy jednak czekać na formalne podpisanie umowy. Pismo wymienia tez konkretne kandydatury, do odznaczeń: prezydent, szef Ministerio de Fomento, sekretarz generalny MSZ, szefowie Protokołu Dyplomatycznego i departamentu kolonizacji, a także dyrektor Departamentu Rolnictwa i Hodowli, mieliby otrzymać Polonia Restituta, k. 124-125; W. T. Drymmer (szef DK MSZ) z podziękowaniami dla W. Dostala, bd, ale zapewne maja, k. 4; Poufne pismo Drymmera o konieczności rychłego przeprowadzenia na miejscu prac przygotowawczych i wysłania misji, na marginesie opracowywania przez MTO umowy koncesyjnej z rządem Peru - zapewne z tego samego czasu, k. 7-8; też Jarnecki, 2010, ss. 103-104.

41 AAN MSZ sygn. 9556-mf. B25966, Sprawozdanie W. Dostala z 16.04.1939, k. 9-15 wraz załącznikiem: „Umowa o imigracji między RP a Peru" (projekt) k. 16-21; Poselstwo z Buenos Aires do MSZ, z 6.05.39 z odręcznie spisanym tekstem i pro memoria W. Dostala mobilizującym do maksymalnie szybkiej finalizacji umowy, ze względu na zachodzące zmiany na peruwiańskiej scenie politycznej i szykujące się w końcu roku zmiany personalne (m.in. prezydenta), k. 109-111.

42 Ibidem, Notatka w sprawie projektu umowy emigracyjnej z Peru, b.d. oraz odręczne zapiski 29.04.39, że należy dążyć do jak najszybszego podpisania "umowy z Buenos Aires" oraz umowy koncesyjnej. Gdyby jednak osadnicy "tegoroczni" nie mogli skorzystać z umowy oraz wewnętrznych ustawowych regulacji, to należy im zapewnić im podobne warunki. Na przyszłe obszary koncesyjne, Tingo Maria ma udać się dwuosobowa misja. W notatce też sugestia, nie pierwsza już, założenia etatowej, stałej placówki w Limie, k. 44-45.
} 
z dokumentów nazywany był ciągle konsulem honorowym, choć w poprzednim roku, najprawdopodobniej Peruwiańczycy mieli z jego usług zrezygnować, z powodu, co wiemy, nie najlepszej atmosfery wokół samego konsulatu. Niewykluczone, iż siłą rozpędu był tak tytułowany, a w MSZ, którego pośrednio też miał być delegatem postawiono na jego profesjonalizm, świetną znajomość języka i kontakty, a nie tyle argumenty moralno-etyczne. $Z$ racji, iż w obu państwach nie istniały profesjonalne placówki dyplomatyczne, paszport Szczerby-Likiernika, został skierowany w maju w celu wizowania do Berlina, gdzie znajdowało się najbliższe peruwiańskie przedstawicielstwo ${ }^{43}$.

Powiązane z resortem spraw zagranicznych MTO, z powodu wyjazdu Likiernika, przesłało do MSZ projekt umowy koncesyjnej, pod którym widniały podpisy znanych już „weteranów" polskiej ekspansji osadniczo-kolonizacyjnej, prezesa M. Lepeckiego i dyrektora M. Paszkiewicza. Rząd Peru miał udzielić MTO koncesji na osadnictwo i zezwolić na swobodny wjazd urzędnikom tej instytucji. Na obszarze przeznaczonym do kolonizacji, zaakceptowanym przez MTO, Towarzystwo zobowiązywało się przeprowadzić akcję osadniczą i zarządzać na bieżąco "kolonią". Koszty administracyjne pokrywał rząd peruwiański i wyznaczał też komisarza kolonizacyjnego, który reprezentował wobec MTO władze wszelkich szczebli. Z kolei MTO miało wytypować swego delegata i zarazem reprezentanta zarządu głównego organizacji. Plan kolonizacyjny (osadniczy) na każdy rok miał być uzgadniany przez komisarza i delegata MTO na 3 miesiące przed upływem poprzedniego. Pod cele osadnictwa rząd Peru wyznaczał odpowiedni obszar, skomunikowany z krajem i zobowiązywał się do wybudowania sieci dróg dostępnych do przewozu dobytku i płodów rolnych. Wytyczał działki osadnicze. Całość miała zostać dokładnie wymierzona prawdopodobnie do końca 1939 roku. Można tak mniemać, ponieważ w innym fragmencie tekstu, miejsce na ilość miesięcy przewidzianych na definitywne wyznaczenie działek, pozostawione pozostało puste. Każda z działek liczyła po 20 ha, z jasno wytyczonymi granicami, a podział uwzględniać powinien dostępność do wody bieżącej. W razie potrzeby MTO, na żądanie Peru, miało dostarczyć, na koszt gospodarza (transfer plus płace) fachowców do przeprowadzenia specjalistycznych prac, choć takich jak wyżej. Owych ekspertów miało być minimum dwóch: 1 inżynier i 1 miernik. Celem zasadniczym było powstanie głównego ośrodka kolonizacyjnego i takowe prace (na koszt Peru) przebiegać powinny rów-

\section{......}

43 Ibidem, Express polecony do Ambasady RP w Berlinie (bd), aby podjąć starania o bezpłatną wizę peruwiańską dla wybierającego się tam na przełomie maja-czerwca K. Szczerby-Likiernika w celu dokonania inspekcji i organizacji osadnictwa, k. 53-54; Szyfrogram do Berlina, z 20.05.1939, g. 12.15 g. 12.15 (wspomniany „najbliższy piątek"), k. 55; Odręczna Notatka z 8.05.1939 do Komisji Dewizowej MSZ do szefa Międzyministerialnej Komisji Emigracyjnej (MKE), dr A. Zarychty, iż do Peru jedzie jako delegat MTO i z ramienia MSZ K. Szczerba-Likiernik, konsul honorowy Peru w Warszawie, koszty pokryte zostaną przez MKE -prośba do Komisji Dewizowej o przydział 9000 zł na zakup dewiz, a czas pobytu i podróży liczony na 5 miesięcy, k. 57; Pismo Likiernika do ambasady peruwiańskiej Berlin z 9.05.1939, iż celem starań o wizę jest dokończenie negocjacji, k. 58; Pismo MTO do MSZ z 25.04.1939 - z prośbą o zaakceptowanie Szczerby-Likiernika na wyjazd do Peru ponieważ nadaje się do tej roli znakomicie: zna świetnie hiszpański, nawiązał kontakty i jest praktykiem, k. 59; Pismo z MTO do sekretariatu MKE, o pomoc w uzyskaniu wizy peruwiańskiej i zezwolenie na wywóz w/w dewiz, k.60; Odpis listu MTO do WE I w DK MSZ, z 27.05.1939 - obok instrukcji dla samego Likiernika. Występuje tam dokładne wyliczenie kosztów, na które przeznaczono 10 tys. zł. Diety wynosity 5625 zł, przejazd do Peru z Polski i powrotny 2900 zł, lokomocja w Peru 1000, a korespondencja 475 zł. Obowiązki zostaną uznane za wypełnione po dostarczeniu wszystkich sprawozdań na piśmie i uznaniu ich za wystarczające, a ich brak będzie uważany za niedopełnienie zobowiązań. Wszelkie zobowiązania MTO kończą się z upływem 4 miesiąca od daty wyjazdu z Warszawy, k. 112; Ambasada RP Berlin do MSZ, 20.05.1939 wysyłka paszportu Szczerby-Likiernika, 20.05.39, k. 97; Szyfrogram z 24.05.1939 z MSZ do "Polmission-Buenos Aires" z informacją, iż Likiernik wypływa statkiem z Hamburga do Callao 31.05.39, k. 99; MSZ sygn. 9557/mf. B 25967, Telegram szyfrowy z Buenos do MSZ, z 26.05.1939 o rezygnacji Peruwiańczyków z Likiernika w roli konsula honorowego, k. 6; WE I MSZ do Poselstwa z Buenos, bd, prawdopodobnie z czerwca 1939 r. W. T. Drymmer odpowiadał, iż pomimo znanego faktu, pozbawienia Likiernika godności konsula, decyzja o posłużeniu się jego osobą, wyszła ze strony resortu, k. 2; Biuro Personalne do Poselstwa w Buenos Aires (2.06.1939) z konkluzją, iż zastrzeżenia wobec Likiernika były raczej pośredniej natury i stąd informacje posła Kurnikowskiego są niedokładne, k. 5. 
nolegle z przybyciem 1 partii imigrantów. W owym centrum rząd gospodarza wydzielał 50 ha pod stację doświadczalną rolniczo-hodowlaną, której obszar byłby zwiększany wraz z napływem emigrantów. Preliminarz tej stacji byłby również układany każdego roku i subsydiowany przez rząd limański. Kierownictwo owej placówki zostałoby powierzony MTO, a z jej efektów osadnicy korzystaliby bezpłatnie. Na terenie głównego ośrodka na koszt Peru miały powstać domy mieszkalne dla administracji MTO oraz sklepy, magazyny, poczta, szkoła, kościół i domki dla pracowników fizycznych. Plany budowy tych pomieszczeń byłyby uzgadniane z MTO (odpowiednim protokołem), a prawa własności do nich przechodziłyby na towarzystwo bezpłatnie. Dla własnych gospodarstw personelu administracji i sklepów prowadzonych przez MTO, rząd miał wydzielić obszar przy wspomnianym centrum 500 ha, z tytułem własności samego towarzystwa. Po 15 latach od rozpoczęcia akcji - wszystkie posiadłości MTO z wyjątkiem dochodowego gospodarstwa doświadczalnego przejść miały na własność Peru. Władze z Limy miały przydzielać osadnikom ziemię bezpłatnie za pośrednictwem i na rzecz MTO, a towarzystwo w ciągu miesiąca od chwili jego zawiadomienia przez peruwiańskiego komisarza, przydzielałoby 20 ha na każdego plus 20 ha na doroste dzieci (18-21 lat) i 10 ha i dla mniejszych pomiędzy 14. a 18. rokiem życia. Tymczasowe akty własności zostałyby zamienione na właściwe po uregulowaniu przez osadnika wszystkich zobowiązań wobec rządu Peru. Gdyby zaś osadnik przed uregulowaniem zobowiązań opuścił swoją działkę, wówczas MTO posiadałoby prawo odsprzedania jej innemu. Rząd peruwiański zgadzał się na udzielanie bezprocentowych pożyczek osadnikom. Sumy pożyczek byłyby ustalane w następujący sposób: rząd wpłaca na rachunek MTO ekwiwalent przemnożenia funtów brytyjskich lub dolarów cyfry 3-krotnego kontyngentu osadniczych rodzin - średnio po 50 rodzin rocznie, a w każdej minimum średnio 3 doroste osoby - przez kwotę stanowiącą 2/3 części karty okrętowej (czyli wówczas biletu na podróż statkiem oceanicznym - M.J.). Pierwsza transza "kolonistów" miała wyruszyć w miesiąc po podpisaniu umowy. MTO posiadało prawo pobierać opłaty a konto kosztów własnych od osadników. Towarzystwo było też zobowiązane przeprowadzić rekrutację, zorganizować transport morski, pomagać w transferze z portu do obszaru kolonizowanego, umieszczać emigrantów w schroniskach przejściowych i opiekować się nimi oraz udzielać pomocy osadnikom. Ich kwalifikacje były sprawdzane przez Peruwiańczyków. Za dostarczone osadnikom towary opłata miała zostać pobrana w Polsce lub w Peru. Towarzystwo posiadałoby też prawo do prowadzenia działalności przemysłowej i wyłączność na sklepy, w celu ochrony osadników przed wyzyskiem. W przypadku odkrycia kopalin prawo do eksploatacji miałoby MTO. Wszystkie świadczenia peruwiańskie wynikające z umowy, a nie zapisane w koncesji byłyby stosowane automatycznie. Towarzystwo mogło też w porozumieniu z komisarzem nabywać nowe tereny pod kolonizację, a wobec kolonistów z RP miały być zastosowane te same ułatwienia i pomoc jak dla peruwiańskich (jeśliby osiedlili na terenach rządowych). W przypadku sporów wynikłych wokół tej umowy, zostałaby powołana komisja arbitrażowa składająca się z przedstawicieli MTO, komisarza i przewodniczącego wybieranego przez strony. Gdyby doszło do impasu przy jego wyborze, zadecydowałby wtedy losowanie. Dla rozstrzygania sporów między MTO, osadnikami, a rządem, właściwe byłyby sądy peruwiańskie. Osadnicy otrzymać mieli takie same prawa jak obywatele Peru. W przypadku zerwania umowy przez stronę peruwiańską, zostałyby zwrócone poniesione koszty poniesione przez MTO. Umowa została sporządzona w dwóch 2 językach i zwolniona z opłat, razem licząc 40 paragrafów ${ }^{44}$. Przed-

\footnotetext{
44 AAN MSZ, sygn. 9556-mf. B25966, Projekt umowy koncesyjnej przesłany z MTO do MSZ, z 23.05.1939, k. 102-108.
} 
stawiony projekt dowodzi wyciągnięcia wniosków z pierwszego niepowodzenia, stąd taka dbałość o zaprezentowane detale.

Udający się nad Pacyfik, Likiernik otrzymał instrukcje i sugestie ewentualnej strategii negocjacyjnej. W swoim raporcie miał opisać obszar kolonizowany obszar, zwracając uwagę na następujące detale: jego wysokość oraz położenie geograficzne, odległość od stolicy i ośrodków miejskich, dostępne środki komunikacyjne, klimat, zdrowotność, gleba, kultury rolne i ich opłacalność, możliwość zarobkowania na terenie kolonii i jej okolicach, dotychczasowe zaludnienie, świadczenia rządowe (wyliczenia i praktyczna ich realizacja) i widoki otrzymania tych świadczeń w przyszłości. Podczas pertraktacji z rządem w sprawie umowy koncesyjnej, miał unikać wszystkiego, co nakładałoby na MTO dodatkowe zobowiązania. Najistotniejszym warunkiem, z punktu widzenia Towarzystwa, było kredytowanie dla osadników 2/3 kosztów przejazdu - bez gwarancji ze strony MTO zwrotu otrzymanego przez osadników kredytu. Miał nie obstawać przy żądaniach świadczeń, które Peru nie będzie w stanie spełnić. Dodatkowo do jego obowiązków należałoby zebranie danych o ważniejszych prywatnych firmach zajmujących się kolonizacją i zbadanie możliwości importu miedzi i innych surowców z Peru do Polski. Co tydzień miał wysyłać pocztą lotniczą sprawozdania czy wnioski, z uwzględnieniem spraw załatwianych na miejscu. We wcześniejszym zaś o osiem dni dokumencie argentyńska placówka sugerowała również, aby instrumentem negocjacji uczynić kwestię obowiązku obsiania 1 ha pod las, na co Peruwiańczycy się nie godzili i od czego, ewentualnie można odstąpić, powtarzając znany już argument wysłania osoby kompetentnej do rokowań i taktycznie nie naciskać na błyskawiczne podpisanie ${ }^{45}$.

Obszary potencjalnej nowej koncesji Tingo Maria leżały wzdłuż szosy łączącej stolicę departamentu-regionu Huánuco o tej samej nazwie, w prowincji Leoncio Prado z miastem Pucallpa nad brzegiem Ucayali. Oddalone były od Limy bitymi drogami pomiędzy 480 a 513 kilometrami. Polacy, w domyśle dobrzy rolnicy, mieli zasiedlić rejony zwane „Własnością średnią" nad brzegami rzeki Tulumayo, 20 km od Tingo. Tereny owe uchodziły na ówczesne standardy za „uzbrojone”, zaś w samym Tingo znajdowała się stacja rolniczo-doświadczalna. Bogate i obfite pastwiska oraz lasy, poprzez wyrąb, zapewniać miały zyski. W pobliżu istniał znaczący ośrodek górnictwa niklu, srebra i miedzi - Cerro de Pasco, skomunikowany dwoma szosami oraz z koleją żelazną z Limą i Callao. Rejon posiadał niemal idealną wysokość - 650 m n.p.m., co eliminowało najgroźniejsze choroby tropikalne i czyniło klimat znośniejszym, stwarzając również świetne warunki do uprawy kawy. Leżał na styku dwóch rzek Monzon i Huallalgi. Ta druga stanowi główny dopływ Marañón, jednego z ramion Amazonki, nosząc nawet miano „wrót Amazonii"46.

Dużą wstrzemięźliwość wobec projektu umowy koncesyjnej wykazywało po wcześniejszych doświadczeniach związanych z Montanią, Ministerstwo Pracy i Opieki Społecznej, przedstawiając w czerwcu swoje uwagi. Wysłane na Wierzbową pismo, dowodziło, iż Peru nie jest specjalnie atrakcyjne dla Polaków, czego dowodem była porażka w Montanii. Nowe obszary koncesyjne zbytnio nie odbiegaty od tych znad Ucayali, Urubamby i Tambo. Pojawił się warunek. Ewentualne zezwolenie MPiOS na werbunek zależy od au-

\section{-....}

45 Ibidem, MTO do tzw. WE I w DK MSZ wraz z pismem do Likiernika, z 27.05.1939, gdzie obok wyliczeń na co przeznaczone sa kwoty z wyznaczonych diet, znalazły się konkretne instrukcje dla samego Likiernika, k. 112 113; Poselstwo w Buenos Aires do MSZ, z 19.05.1939, gdzie obok kwestii taktyki negocjacyjnej, sugestia aby nie naciskać zbyt mocno, co sprawiałoby wrażenie, iż Polsce bardzo na tym zależy, k. 124-125.

46 Ibidem, Poselstwo w Buenos Aires do MSZ z 19.05.1939, k. 127-128-132, gdzie znalazł się opis Tingo Marii i jej okolic, wraz z załączoną mapą; też podstawowe informacje w hiszpańskojęzycznej wersji popularnego portalu, http://es.wikipedia.org/wiki/Tingo_Mar\%C3\%ADa („Tingo Maria”, b.d.) 
torytatywnego oświadczenia MSZ, że Tingo Maria nadaje się do kolonizowania. W ten sposób jeden resort chciał podzielić się odpowiedzialnością z drugim ${ }^{47}$.

Jak to często bywa, pojawiły się spory o interpretację konkretnych zapisów umowy międzyrządowej czy przewidywanej, na jej bazie, koncesji. Niezależnie od faktu życzliwości najwyższych peruwiańskich czynników, mobilizowanych przez konsula Tarnawieckiego („,bombardowat” urząd prezydenta), gospodarze wprowadzili pewne zmiany. Dotyczyły one głównie: art. 9, w którym Peruwiańczycy domagali się, aby osadnicy rekrutowali się spośród chrześcijan, art. 11, gdzie oczekiwali, aby osadnictwo polskie posiadało charakter rolniczy (minimum 10 lat), art. 8 dotyczącego szkolnictwa, ponieważ strona rządowa oczekiwała prymatu języka hiszpańskiego i marginalizacji zajęć prowadzonych w języku polskim, a także art. 12, w którym Lima oczekiwała, iż o ile kolonista sprzedałby przed upływem 2 lat wwiezione bez cła przedmioty, to MTO owe cło uiści. Strona polska proponowała, aby art. 9 w formie oczekiwanej przez Peru, przenieść do "noty tajnej”, czyli nieupublicznionego załącznika, ze względu na jego niedwuznaczny antyżydowski wydźwięk. Nalegała też, aby obok, co zrozumiałe, kursu historii i geografii Peru w języku państwowym, odbywały się zajęcia w języku polskim na koszt rządu. Nie kwapiła się też do płatności ceł. Z kolei zaś kwestia tycząca się art. 11 miała definitywnie zostać rozstrzygnięta przez koncesję, która uchyliłaby furtkę dla nie-rolników. Poselstwo argentyńsko-peruwiańskie RP (K.Z. Kurnikowski) z siedzibą w Buenos Aires, relacjonujące sprawę, prosiło także o pilne instrukcje. Strona polska kładła nacisk, aby rząd peruwiański gwarantował bezpłatnie materiały budowlane o wartości 300 soli oraz narzędzia - minimum 30 soli. Wracała kwestia preferencji dla wyznawców różnych odmian chrześcijaństwa, czego Polacy usiłowali uniknąć, zwłaszcza w jawnej części umowy. Z kolei peruwiański poseł w Buenos, niezorientowany w sprawie i zaskoczony, nie był w stanie rozwiązać od ręki spraw budzących rozbieżności. W samym resorcie, doradcy prawni stwierdzili, iż kwestie budzące kontrowersje są w sumie nieistotne i drugorzędne ${ }^{48}$. Także MPiOS stało na stanowisku, że należy dążyć do zawarcia umowy szerszej, dotyczącej nie tylko kwestii rolników, a jeśli się nie dałoby tego przeprowadzić, to choćby dopuścić ok. 20\% osadników innych zawodów czy specjalizacji. Należałoby też zagwarantować prawo do zabrania członków rodziny przynajmniej do drugiego stopnia pokrewieństwa oraz starać się skrócić 10 letni okres pracy na gospodarstwie rolnym do może czterech czy pięciu lat. Wreszcie niezbędna byłaby również gwarancja zapewnienia emigrantom pobierania nauki w języku polskim i wiedzy o Polsce, z uwzględnieniem oczywiście, jak napisano w oryginale, nauki „języka peruwiańskiego", zaś kontrakt nie powinien być zerwany przed upływem 10 lat ${ }^{49}$.

Pozycji Szczerby-Likiernika nie ułatwiał fakt, iż Peru początkowo nie uznawało MTO w roli partnera, a eks-konsul był przecież jego delegatem, stąd pewna dwuznaczność jego misji. Sam doradzał, w czym był zgodny z polskim konsulem honorowym, intensyfikację nieformalnych kontaktów z lokalnymi notablami, z prezydentem włącznie, w celu promo-

\section{......}

47 AAN MSZ, sygn. 9557-mf. B 25967, MPiOS do MSZ, 9.06.1939, k. 7-8.

48 Ibidem, Poselstwo Buenos Aires do DK MSZ, z 5.06.1939 do MSZ, k. 9-13; Projekt ze strony MSZ skierowany do Poselstwa w Buenos Aires, z 7.06.39, z uwzględnieniem, co powinno zostać objęte gwarancją, k. 23-27, 47 oraz odpis raz jeszcze w języku hiszpańskim, k. 32-33;Uwagi naczelnika Wydziału Prawnego, wg niego mało istotne różnice-ręczny zapisek z 19.07.1939, k. 82-83; Poselstwo z Buenos Aires do MSZ, z 17.06.1939, stwierdzający, iż problemem może stać się renegocjacja umowy wraz z odpowiedzią niezorientowanego w detalach posła Peru Felipe Barreda Laosa, z 15.06.1939, k. 56 i 57; Telegram z MSZ do „Polmission" w Buenos Aires, z 17.06.1939, że nowy projekt budzi zastrzeżenia, k. 55; Tłumaczenie noty MSZ do rządu peruwiańskiego z 14.06.1939, ze względu na zmiany wprowadzone do projektu, propozycje uściślenia i poprawek, aby sfinalizować umowę, k. 66-68; Uwagi naczelnika Wydziału Prawnego, wg którego różnice są mało istotne różnice, ręcznie zapisek z 19.07.1939, k. 82-83; kwestia niepodnoszenia oficjalnie warunku bycia wyznawcą chrześcijaństwa, bd, k. 84-86.

49 Ibidem, MPiOS do W.E. I MSZ o konieczności zwarcia szerszej umowy, k. 94 i 96. 
cji polskich postulatów, ponieważ renegocjacja w grę wchodzić nie mogła. Ponoć peruwiańskie urzędy uważały sprawę za przesadzoną ${ }^{50}$.

Niezależnie od komplikującej się sytuacji międzynarodowej i rosnącego zagrożenia Polski, na ulicy Wierzbowej pamiętano o konieczności finalizacji umowy i koncesji z Peru. Poseł Kurnikowski został wyposażony w pełnomocnictwa, a w końcu lipca zapadła decyzja, aby prowadzić negocjacje w sprawie koncesji, niezależnie od niemal gotowej umowy imigracyjnej. Komplikowała się kwestia gwarancji kredytowania lub zwrotu 2/3 kosztów przejazdu przez ocean. Swój sprzeciw w kwestii rozdzielenia dwóch kwestii, zgłaszało MTO, świadome swej słabości negocjacyjnej w przypadku rozdzielenia obu problemów. Zachowały sięzapiski dowodzące toczących się rozmów w sprawie peruwiańskiej umowy, jeszcze z pierwszej dekady sierpnia, gdzie MSZ sugerowało zmiany: w art. 1 należało skreślić, że osadnictwo posiada wyłącznie rolniczy charakter, w art. 3 powinno się podkreślić bezwarunkowe zwolnienie z podatków, w art. 4 - tereny nie tyle mają być wyznaczone, a przygotowane, w art. 5 zarząd kolonii ma być wyznaczony przez rząd Peru w porozumieniu z MTO, art. 9 należy przesunąć do tajnej noty, zaś w art. 11 powinno się skrócić obowiązek na roli z 10 do 3 lat i samą powinność zawodu rolnika ${ }^{51}$. Co ciekawe, w jednej z teczek w warszawskim AAN, jest kilka zapisków, datowanych już w tragicznym wrześniu 1939 r., o ile oczywiście dokumenty są autentyczne i nie została tam popełniona pomyłka w datacji, co niewykluczone. Są to dwa raporty Likiernika o występujących kłopotach w prowadzonych rozmowach, nagłej opryskliwości w peruwiańskim MSZ. Przypominał o nacisku kładzionym przez Limę na rolniczy charakter osadnictwa-kolonizacji i niechęci gospodarzy do pokrywania kosztów przejazdu oraz ich życzeniu, aby kwestię emigrantów żydowskiego pochodzenia potraktować oddzielnie. Ze względu na dobre skomunikowanie rejonu Huánuco - Tingo Maria, obszary są na tyle atrakcyjnie, że należy się spieszyć, aby nie zostać wyprzedzonym - stwierdzał w konkluzjach ${ }^{52}$.

Ze względu na znane wydarzenia ostatniego kwartału 1939 r. nie doszło do podpisania niemal gotowej umowy i koncesji, ale podjęte kroki dowodziły przeanalizowania porażki sprzed niespełna dekady. Tym razem sprawę pilotowało od samego początku państwo.

\section{WNIOSKI}

Druga Rzeczpospolita usiłowała poprzez emigrację nadwyżek prężnej demograficznie ludności, szczególnie wiejskiej oraz z grona mniejszości narodowych, rozładować swoje nabrzmiałe problemy społeczno-ekonomiczne. Stymulacja mobilności własnej populacji, miała być powiązana z ekspansją gospodarczą, poszukiwaniem rynków zbytu czy cennych

\section{....}

50 Ibidem, MTO do MSZ z 3.06.1939, z prośbą o powiadomienie Konsulatu w Peru, że Towarzystwo jest instytucją wyznaczoną przez do przeprowadzenia kolonizacji, a Likiernik jest jego delegatem, k. 90; MTO do Wydziału Emigracyjnego MSZ oraz załącznik w postaci listu Likiernika, bd, ale z kontekstu wynika, że to prawdopodobnie lipiec, o takim postrzeganiu MTO. Towarzystwo należy odpowiednio „zaawizować”, o czym rozmawiał z konsulem Tarnawieckim.Za zmiany w tekście, stoją konkretni ludzie, niewykluczone, że i z niemieckiej diaspory [M.J.]. Najlepszym rozwiązaniem byłoby upoważnienie „kogoś" na miejscu, najlepiej z konsulatu do prowadzenia negocjacji i podpisania umowy międzypaństwowej. Zalecał też nieformalne drogi „dojścia", np. prezydenta w ramach "cocktail party", k. 46.

51 Wydziat Konsularny MSZ z pełnomocnictwami dla Z. Kurnikowskiego w Buenos Aires, lipiec 1939, z uwagami o potencjalnej strategii negocjacyjnej, k. 87-88; sprzeciw MTO, 26.07.1939, k. 92; DK - W. E. I MSZ do Poselstwa z Buenos Aires, 9.08.1939, z sugestiami zmian w konkretnych artykułach, k. 52-53.

52 K. Szczerba-Likiernik do MTO (odpis) z 11.09 .1939 (?) o występujących trudnościach w MSZ, k. 49-50; Honorowy Konsulat Gen. RP w Peru do MSZ z załącznikiem w postaci pisma-raportu Szczerby-Likiernika z 12.09.1939 (?), inf. o swojej podróży jako konsula honorowego w kwestii umowy imigracyjnej, głównie o rozmowach w Ministerstwie Gospodarstwa, k. 104-105. 
surowców, potrzebnych do rozwoju przemysłu. Takie ujęcie zagadnienia nadawało mu sens, choć na użytek wewnętrzny - rzadziej na arenie międzynarodowej, często używana była retoryka sugerująca potrzebę czy konieczność posiadania kolonii. De facto pod tymi hasłami kryło się przede wszystkim poszukiwanie w Ameryce Łacińskiej bądź Afryce miejsc gotowych i dogodnych do przyjęcia przybyszów z Polski.

Nie wszystkie działania $w$ tym kierunku poprzedzone zostały niezbędnymi analizami czy właściwym doborem ludzi, nazywanych w tym przypadku "materiałem osadniczym". Odpowiednie działania zostały zapoczątkowane już w końcu lat dwudziestych. Już same analizy i wnioski z nich wysunięte podczas wstępnej misji z 1928 r. okazały się pochopne. Oczekiwania na szybki sukces rodziły pokusy drogi na skróty i poszukiwanie prywatnych inicjatyw osadniczych, co zmniejszyłoby koszty samego państwa. Opisany przypadek posiadał właśnie taki charakter. Być może użycie w jednym z internetowych portali historycznych, określenia „dzika kolonizacja”, pod adresem peruwiańskiej Montanii na przetomie lat dwudziestych i trzydziestych, jest zbyt mocne, ale bliskie prawdy (blogpress). Nieprzemyślane kroki przyniosły spektakularną porażkę, z której państwowe instytucje odpowiedzialne za kwestie emigracji, długo nie mogły się otrząsnąć, ale wyciągnęły też lekcję, aby nie powierzać tak odpowiedzialnych zadań tylko amatorom, osobom oraz inicjatywom prywatnym, nawet jeśli kierowatby nimi najszlachetniejsze pobudki. W grę wchodził przecież wizerunek i prestiż Polski poza jej granicami. To właśnie spowoduje, że władze II RP zdając sobie sprawę, iż został on nadwątlony, wezmą na siebie odpowiedzialność i wyprowadzą na własny koszt z koncesji Kolonii Polskiej żądających tego osadników. Z koncesji Syndykatu, po pierwszym zetknięciu, uciekli wcześniej. W drugim „podejściu", w końcu lat trzydziestych, zadanie wynegocjowania i podpisania odpowiednich umów czy koncesji wzięły na siebie wyspecjalizowane instytucje państwa, jak zawodowi dyplomaci i MTO. Przesłanek porażki należy upatrywać w niewłaściwej, pospiesznej organizacji całej akcji, braku jasnej koncepcji, nadmiernych obietnicach obu organizatorów, zwłaszcza Syndykatu, wspomnianym kilkakrotnie niewłaściwym doborze osadników (zastosowano zasadę "jak leci"), nieuczciwości zarządu Syndykatu, braku kapitałów - wymuszający system koncesyjny, choć nie zawsze pieniądze były gwarancją sukcesu. Henry Ford też poniósł porażkę przy próbie założenia plantacji kauczuku. Środki i przemyślany plan oraz sposób niewątpliwie zwiększyłby szanse osadnictwa. Jak wspominał S. Warchałowski, „najbardziej udany był system japoński, który polegał na kupowaniu (a nie staraniach o koncesję) dużych połaci ziemi i osadzaniu osadników w ramach kooperatyw). System ten przejęli również Holendrzy. Polskie próby zaś [...], opierały się na koncesjach rządu, czyli użytku ziemi jeszcze nie zajętej[...]. Najlepsze ziemie zawsze były już zajęte i pozostawały raczej nieużytki, albo o trudnym dostępie"(S. Warchałowski, 2009, s. 228). Osadnicy znacznie oddaleni od tzw. centrów cywilizacji, poza wyjątkami pozbawieni własnych środków transportu, byli zdani na prawie monopolistyczne praktyki właścicieli łodzi, stanowiących tutaj podstawę komunikacji. Tzw. lancheros, w istocie lokalni pośrednicy, dyktowali więc ceny swoich usług jak i produktów oferowanych przez kolonistów. Te drugie, w określonym kontekście początku lat trzydziestych nie mogły być wysokie. Sytuację pogłębił kryzys gospodarczy pociągający nagły spadek cen na wszelakie surowce. Po stronie polskiej też dołożyła się ignorancja i rutyna urzędnicza. Przykładem niewiedzy o odległościach w Peru decydentów z Warszawy, niech będzie fakt wyposażania przyjezdnych w bilet do lquitos, a stąd jeszcze było kilka dni drogi do Cumarii w dół Marañón i Ucayali (S. Warchałowski, 2009, s. 228). 
Sam K. Warchałowski starał się bronić przed często niesprawiedliwymi oskarżeniami, a imię ojca starł się chronić, co zrozumiałe jego syn Stanisław na kartach swego pamiętnika. Wziąwszy na swoje barki zbyt dużą odpowiedzialność, nie przewidziat, że sytuacja go przerośnie. Liderzy Spółdzielni „Kolonia Polska”, w tym i on odrzucali oskarżenia o nieuczciwość i podkreślali, iż majątku się na sprawie nie dorobili, iż należeli do grona ludzi „czystych rąk”. To prawda, ale i czas był za krótki, aby zdobyć wymierne zyski, jednak zapewne bezwiednie przyczynili się do zrujnowania szeregu osób (Bochdan-Niedenthal, 1935, s. 138).

Na jeszcze jeden aspekt sprawy zwrócit uwagę Edward Urbański, iż do prac przygotowawczych, a zwłaszcza rekonesansu w 1928 r., nie został zaproszony znawca przyrody peruwiańskiej, albo poproszony o opinię, W. Szyszłło mający własne krytyczne zdanie, co dowodziłoby albo pewności siebie polskich ekspertów, albo uprzedzeń, od których w Polsce nie jesteśmy wolni (Urbański, 1991, ss. 162-164, 186).

Zespół wielu czynników doprowadził do fiaska pierwszej próby skierowania do Peru większej grupy polskich emigrantów. Czołową rolę odegrały błędy ludzkie, w mniejszym międzynarodowy kontekst. Drugie podejście u schyłku dekady lat trzydziestych, posiadato spore szanse sukcesu, porozumienie było na wyciągnięcie ręki. Wykorzystane zostały formalne i nieformalne sposoby i drogi dojścia do decydentów. W finalizacji przeszkodził jednak czynnik niezależny od umawiających się stron, u schyłku lata 1939 r. - burza dziejowa, która początek swój mając w Europie, ogarnęła niemal cały świat.

\section{BIBIOGRAFIA}

Aguia Branca. (b.d.). Pobrano 17 listopada 2011, z http://pt.wikipedia.org/wiki/\%C3\%81guia_ Branca

Białas, T. (1986). Liga Morska i Kolonialna 1930-1939. Gdańsk: Wydawnictwo Morskie.

Bochdan-Niedenthal, M. (1935). Ucayali: raj czy piekło nad Amazonką. Warszawa: Wydawnictwo P. Pyz.

Fiktus, P. (2012). „Nowa Polska” w polskiej myśli kolonialnej do 1939 r. W M. Sadowski \& P. Szymaniec (Red.), Acta Erasmiana (T. 2: Prace z myśli polityczno-prawnej oraz prawa publicznego, ss. 117-121). Wrocław: Wydział Prawa, Administracji i Ekonomii Uniwersytetu Wrocławskiego. Pobrano 27 października 2013, z http://www.bibliotekacyfrowa.pl/Content/40273/001.pdf

Jarnecki, M. (2010). Fantastyka polityczna czy konieczność? Portugalska Afryka, Nikaragua, Boliwia, Ekwador w polskich planach kolonialnych. Sprawy Narodowościowe. Seria Nowa, (10), 93-94.

Kochanek, K. (1979). Los Polacos en el Peru. Lima: Editorial Salesiana.

Kolonizacja w „Montanii”. (b.d.). Pobrano 25 listopada 2013, z http://www.blogpress.pl/ node/12512

Kopeć, K. (b.d.). II RP wobec problemu wychodźstwa: regulacje prawne, kolonie, faktorie. Pobrano 30 października 2013, z http://www.krzysztofkopec.pl/podstrony/historia/emigracja.html

Lepecki, M. (1930). Opis polskich terenów kolonizacyjnych w Peru. Warszawa: Naukowy Instytut Emigracyjny. 
Łossowski, P. (Red.). (1995). Historia dyplomacji polskiej (T. 4: 1918-1939). Warszawa: PWN Mazurek, J. (2009). Rodzina Warchałowskich: próba portretu zbiorowego. W S. Warchatowski, I poleciał w świat daleki...: wspomnienia z Brazylii, Polski i Peru. Warszawa: Instytut Studiów Iberyjskich i Iberoamerykańskich UW, Muzeum Historii Polskiego Ruchu Ludowego.

Pankiewicz, M. (1916). Z Parany i o Paranie. Kraków: Gebethner i Wolff.

Paradowska, M. (1977). Polacy w Ameryce Południowej. Wrocław: Ossolineum.

Parlamentarzyści RP. (b.d.). Pobrano 2 grudnia 2013, z bs.sejm.gov.pl

Penal del Sepa. (b.d.-a). Pobrano 20 listopada 2013, z http://mapcarta.com/20203210

Penal del Sepa. (b.d.-b). Pobrano 20 listopada 2013, z http://es.wikipedia.org/wiki/Colonia_Penal_del_Sepa

Provincias del Perú. (b.d.). Pobrano 1 listopada 2013, z http://es.wikipedia.org/wiki/Provincias_del_Per\%C3\%BA

Rodríguez, F. (Red.). (1998). Relacje Polska - Peru: historia i wspótczesność. Warszawa: Centro de Estudios Latinoamericanos Universidad de Varsovia.

Rozporządzenie Rady Ministrów z 22 kwietnia 1920 r. w przedmiocie utworzenia Urzędu Emigracyjnego przy Ministerstwie Pracy i Opieki Społecznej. (1920, kwiecień 22). Dz. U. RP nr 39, poz. 232.

Skrzypek, A. (1995). W kręgu koncepcji Międzymorza i taktyki balansowania (maj 1935-wrzesień 1939). W P. Łossowski (Red.), Historia dyplomacji polskiej (T. 4: 19181939, ss. 493-572). Warszawa: PWN.

Smolana, K. (2001). Szyszłło Witold (1881-1963). Portal polskiej ambasady w Limie. Pobrano 4 listopada 2013, z http://www.lima.msz.gov.pl/pl/wspolpraca_dwustronna/ 90polskaperu/ralacje_dyplomatyczne/szyszllo/

Sokót, F. (1931, październik 25). Prawda o Peru. Gazeta Świąteczna.

Szyszłło, W. (1955). La naturaleza en la América Ecuatorial. Observacionesbotánica en la regiónamazónica del Perú, Brasil, Bolivia, Ecuador, Colombia, Venezuela y la Guyanaentre 1904 y 1953 durante doce viaje scientificos. Lima: 1955.

Tingo Maria. (b.d.). Pobrano 25 listopada 2013, z http://es.wikipedia.org/wiki/Tingo_ Mar\%C3\%ADa

Urbański, E. S. (1991). Sylwetki polskie w Ameryce tacińskiej w XIX i XX wieku: uczeni, literaci, artyści, kler i wojskowi (T. 2). Stevens Point: Artex.

Warchałowski, K. (1930). Peru: warunki gospodarcze Montanii Peruwiańskiej. Warszawa: nakł. "Kolonji Polskiej”.

Warchałowski, S. (2009). I poleciał w świat daleki...: wspomnienia z Brazylii, Polski i Peru. Warszawa: Instytut Studiów Iberyjskich i Iberoamerykańskich UW, Muzeum Historii Polskiego Ruchu Ludowego.

Wrzesiński, W. (2002). Polityka państwa polskiego wobec Polaków za granicą w latach 1918-1939. W W. Wrzesiński, Między Królewcem, Warszawą, Berlinem a Londynem: szkice i studia z dziejów XX w. (T. 1). Toruń: Wydawnictwo Adam Marszałek.

Zahoro, M. (2010). Polska kolonizacja nad Ukajali w kontekście dziejów Polonii peruwiańskiej na przełomie wieków XIX i XX. Pobrano 29 października 2013, z http://www.latino.starcode.pl/9,quotpolska_kolonizacja_nad_ukajali_w_kontekscie_dziejow_polonii_ peruwianskiej_na_przelomie_wiekow_xix_i_xxquot_marta_zahoro.html 